\title{
The Effects of Topography on Martinique's Mesological and Floristic Differentiations: the Case of Morne Carrière (Commune of VAUCLIN).
}

\author{
Philippe Joseph ${ }^{1}{ }^{2}$, Jean-Émile Symphor ${ }^{2}$, Kévine Baillard ${ }^{1}, 2$, Séverine \\ Elymarius ${ }^{1},{ }^{2}$, Jean-Philippe Claude ${ }^{1},{ }^{2}$, Yelji Abati ${ }^{1},{ }^{2}$, Yanis Jean-françois ${ }^{1}{ }^{2}$ \\ UMR ESPACE DEV (1), BIORECA (2), University Of The French Antilles (Martinique)
}

\begin{abstract}
At planetary as well as local scale, the relief forms induce spatial modifications of the structure of the main bioclimatic factors such as temperature, rainfall, humidity, insolation, evaporation and nebulosity. Depending on the area under consideration, these changes result in more or less strong floristic gradients. We wanted to study this phenomenon in the Lesser Antilles (island microsystems). We carried out floristic surveys in circa twenty stations within the vegetation cover of a hill in the south of Martinique influenced by the dry bioclimate (summit at 200 meters altitude). These stations have been placed on the windward (East side) and leeward (West side) slopes. Among the latter, the data analysis allowed us to demonstrate mesological (biotope) and therefore floristic differentiations. In fact, the ecological conditions of the slope protected from the wind allow the installation of typical mesophilic environment species in small populations. This phenomenon of mesological differentiation due to the topography is an important element which in large part explains the multiplicity of plant formations in the Lesser Antilles.

Keywords: Lesser Antilles, Martinique, Topography, Flora, Mesological factors.
\end{abstract}

\section{Introduction}

Like the other Lesser Antilles, Martinique is the result of an intra-oceanic subduction between the Caribbean tectonic plate and that of North America [1][2]. The different phases of its construction resulted in a highly contrasted geomorphology [3]. In fact, the many topographic facies such as the slopes protected from the wind, the confined or encased valleys modify the main mesological factors, in principal the water resources [4] [5-11]. The mesological differentiations due to the topographic gradient can be observed elsewhere in the world within the different biomes [12-16]. However, in smaller islands such as the Lesser Antilles, they occur in short distances [17-20]. In fact, the small hills called "Mornes" initiate significant biocenotic variations between the windward and leeward slopes. Using plant surveys carried out on 20 stations at Morne Carrière in Martinique's xeric southern region, we have attempted to shed light on the main determinisms of plant topo-sequences (Fig. 1 $\&$ 2)[21]. The surveys will first allow us to describe the stations individually and then we'll use them in global analyses, in particular factorial analyses. Our aim is to try to highlight the spatial differences, both physical and biological.

\section{Physical Context}

The south-east of Martinique is characterized by a rather varied topography: hills called mornes, valleys, slopes [22]. The Mornes are numerous and peak between 200 and 400 meters. The valleys associated with them are more or less confined. In the foothills of the hills, we find the relatively flat coastal zone located almost at the ocean's altitudinal level. The study site (Le Morne Carrière) is mainly occupied by dense secondary vegetation composed of various physiognomic units (Fig. 1). 3D modelling shows the geomorphology of the floristic surveys area (Fig. 1). It is therefore easier to distinguish this hill (the Morne Carrière) at circa 200 meters of altitude. The slopes are on the whole regular and moderate. Nevertheless in certain places the topographic surface shows a strong slope in principal the eastern side (Fig. 2). 


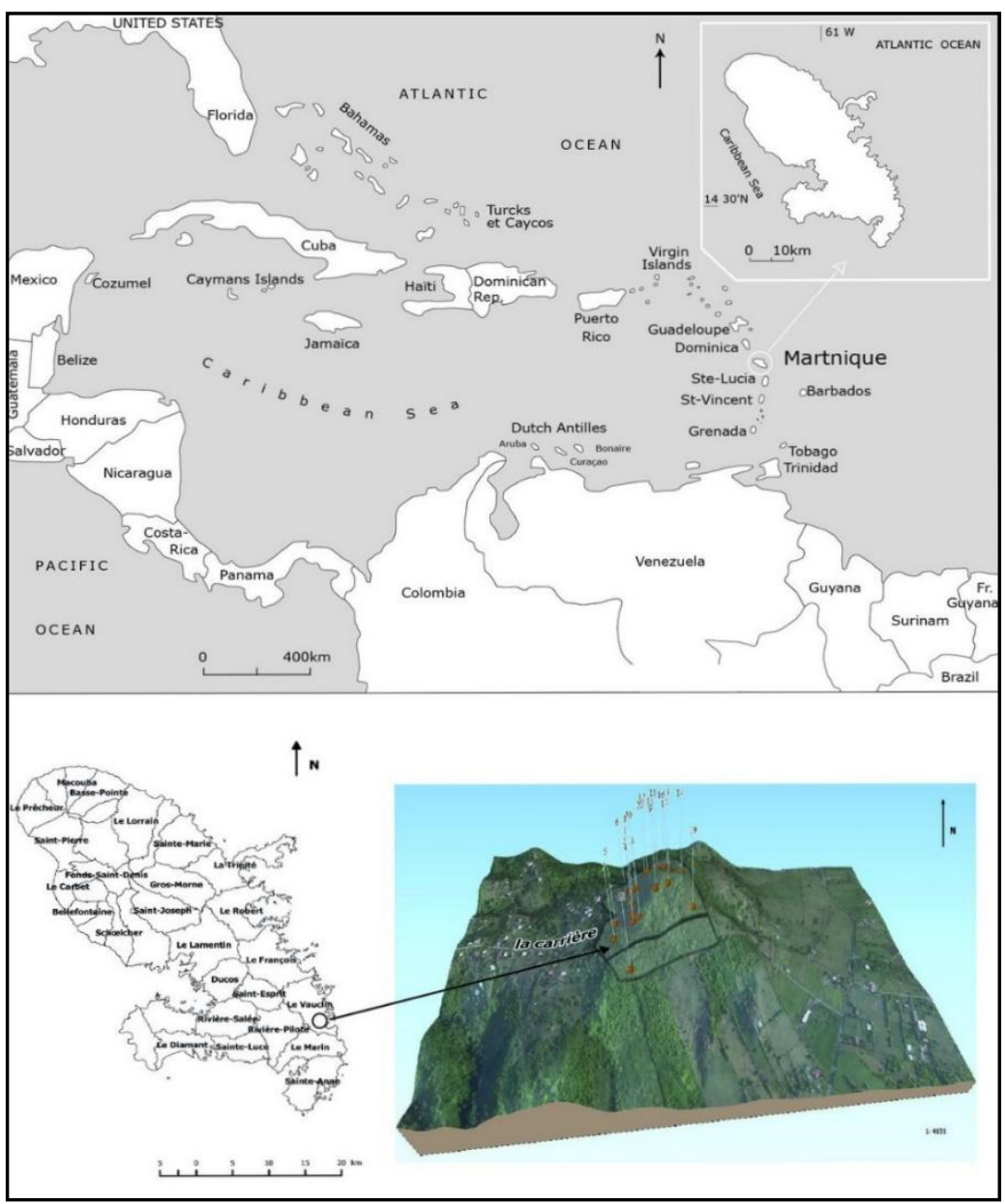

Figure 1: Martinique in the Caribbean - Geo-referenced survey stations in Vauclin

The study area is characterized by minimal annual mean temperatures of $23.3^{\circ} \mathrm{C}$ and average annual maximal temperatures of $28.4^{\circ} \mathrm{C}$. The average annual temperature is $25.8^{\circ} \mathrm{C}$ and corresponds to the average annual temperature of the island, in other words $26^{\circ} \mathrm{C}$. In view of the total monthly precipitation measured by the nearest national meteorological stations, from a climatic point of view this area is a dry environment. The dry period lasts about five months from January to May (Lent), while the rainy season encompasses seven months from June to December (winter), although it is not an exceptional period because the monthly precipitations do not exceed $250 \mathrm{~mm}$. However, the topography can lead to some modifications. The above mentioned precipitation characteristics are evidence of a dry bioclimate and a transition towards a moderately wet bioclimate within certain topographic characteristics. The biocenotic potentialities are variable and are a function of the latter (the topographic characteristics).

From a pedological point of view, the soils are of the Vertical type, Vertisols. These are generally A (B) C soils, derived from parent rocks of a varied nature and located in dry regions, particularly in low rainfall coastal areas. The clay consists of montmorillonite which on the surface results in a typical 10-15 cm dark brown A layer which is relatively low in organic matter (2-4\%). There are few individual iron hydroxides. These soils contract strongly during the dry periods, crumbling at the surface and cracking in depth. The $\mathrm{pH}$ is 4.5 to, rarely, 6.

\section{Data Collection And Analysis}

The methods used to collect and analyse the data correspond to the methodological field specific to macro-ecology [23-25]. The objective is to decipher the structural and functional dimensions of the vegetation. Using transects subdivided into quadrats placed on the various topographic facies and as a function of the minimal survey area (between 400 and $1000 \mathrm{~m}^{2}$ ), we have generated data which have as many ecological descriptors as floristic ones (biodemographic aspects, Fig. 2 and 3): -species, numbers of the plant species population individuals (from regenerations to mature specimens), diameter classes (sections measured at $1.33 \mathrm{~m}$ from the ground in accordance with the international standards), total height classes and first estimated ramifications. 


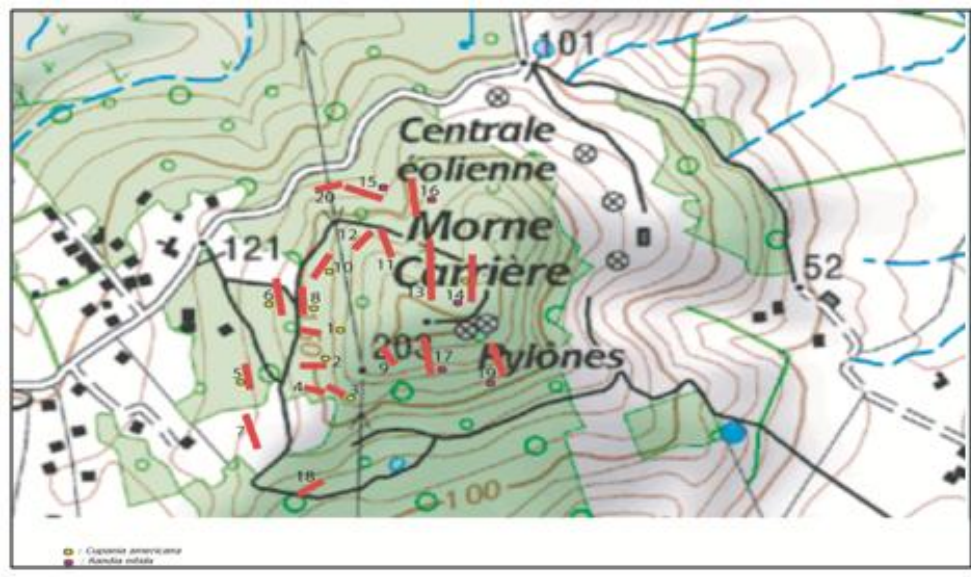

Figure 2: Geo-referenced survey stations

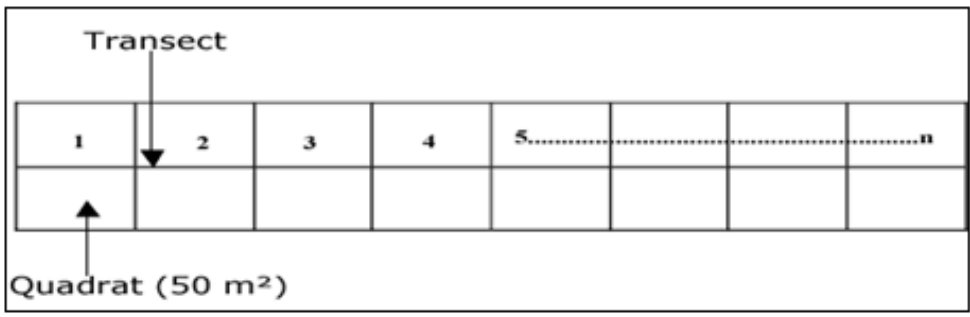

Figure 3: The unit of floristic surveys

These elements allowed us:

- to assess the distribution of the individuals' diameters, the architecture of the formations, the characteristics of the canopies,

- to evaluate the phytomass or biovolume using the basal area $(\mathrm{St})$ which corresponds to the sum of the surfaces of the circles created by the sections measured at 1.33 meters from the ground (international standard).

- to know the distribution of species between the transect quadrats and between the stations using the distribution index which corresponds to the following formula: $\mathrm{Id}=\mathrm{fr} \times \mathrm{d}$ (fr being the relative frequency [fa (absolute frequency)/number of quadrats or stations] and $\mathrm{d}(\mathrm{nb} / \mathrm{sr}$ ) the density [number of individuals of the species (nb) divided by the survey area (sr)].

- to know the relative dominance of the plant species in relation to each other by means of the Dominance Index (ID). ID $=\mathrm{Id} \times \mathrm{St}$ (Basal area).

The comparison between the stations was possible due to a factorial correspondence analysis (AFC) carried out using the XLSTAT software (new version). The relations between species within and between stations have been explored with the SimpleKmeans and EM (Expectation, Maximization) algorithms commonly used for the implementation of clustering techniques [26].

4.1 General characteristics of the stations

\section{Results}

In this section we will present the data of the various survey stations with some interpretation elements.

\subsubsection{Station 1 (500 $\mathrm{m}^{2}$, Fig. 4)}

Table 1: Key Ecological and Structural Parameters

\begin{tabular}{|l|l|l|l|l|l|l|l|l|}
\hline Species & Family & Af & Rf & $\begin{array}{l}\text { Number of } \\
\text { individuals by } \\
\text { species excluding } \\
\text { regeneration }\end{array}$ & Density & $\begin{array}{l}\text { Distribution } \\
\text { Index }\end{array}$ & $\begin{array}{l}\text { Total basal } \\
\text { area by } \\
\text { species }\end{array}$ & $\begin{array}{l}\text { Index of } \\
\text { Dominance }\end{array}$ \\
\hline $\begin{array}{l}\text { Citharexylum } \\
\text { spinosum }\end{array}$ & Verbenaceae & 5 & $100 \%$ & 47 & 0.094 & 0.094 & 0.62652813 & 0.058893644 \\
\hline $\begin{array}{l}\text { Morinda } \\
\text { citrifolia }\end{array}$ & Rubiaceae & 4 & $80 \%$ & 64 & 0.128 & 0.1024 & 0.17956875 & 0.01838784 \\
\hline $\begin{array}{l}\text { Capparis } \\
\text { baducca }\end{array}$ & Capparaceae & 5 & $100 \%$ & 104 & 0.208 & 0.208 & 0.06132813 & 0.012756251 \\
\hline Inga laurina & Mimosaceae & 5 & $100 \%$ & 35 & 0.07 & 0.07 & 0.18202188 & 0.012741532 \\
\hline
\end{tabular}


The effects of topography on Martinique's mesological and floristic differentiations: the case of

Absolute frequency $(A f)$ : presence of the species in the different quadrats. / Relative frequency $(R f)=$ Absolute frequency / number of quadrats / Density = number of individuals /survey area $/$ Distribution index $=$ Relative frequency $\times$ Density $/$ Dominance index $=$ Distribution index $\times$ Land surface $($ basal area $)$.

The ecologically dominant species of this tropical seasonal evergreen forest in the young forest stage (young mesophilic forest) are Citharexylum spinosum, Morinda citrifolia, Capparis baducca and Inga laurina. In this predominant population Citharexylum spinosum is the most competing species. Its Dominance Index is on average four times that of the other three species. This is related to a much higher maximal relative frequency and basal area compared to other taxa (species).This notwithstanding a number, density and distribution index among the lowest. In fact, most representatives of the other species of this phytocenosis (plant association) are undergoing a phase of morphogenetic expansion (development phase) and form a dense matrix of small section individuals (between 2.5 and $5 \mathrm{~cm}$ ) which peak between 1 and $8 \mathrm{~m}$ (Fig. 4). Mature trees at the terminal stage of their development emerge from this matrix such as in order of importance: Citharexylum spinosum, Inga laurina, Simarouba amara, Pisonia fragrans and Cordia sulcata.

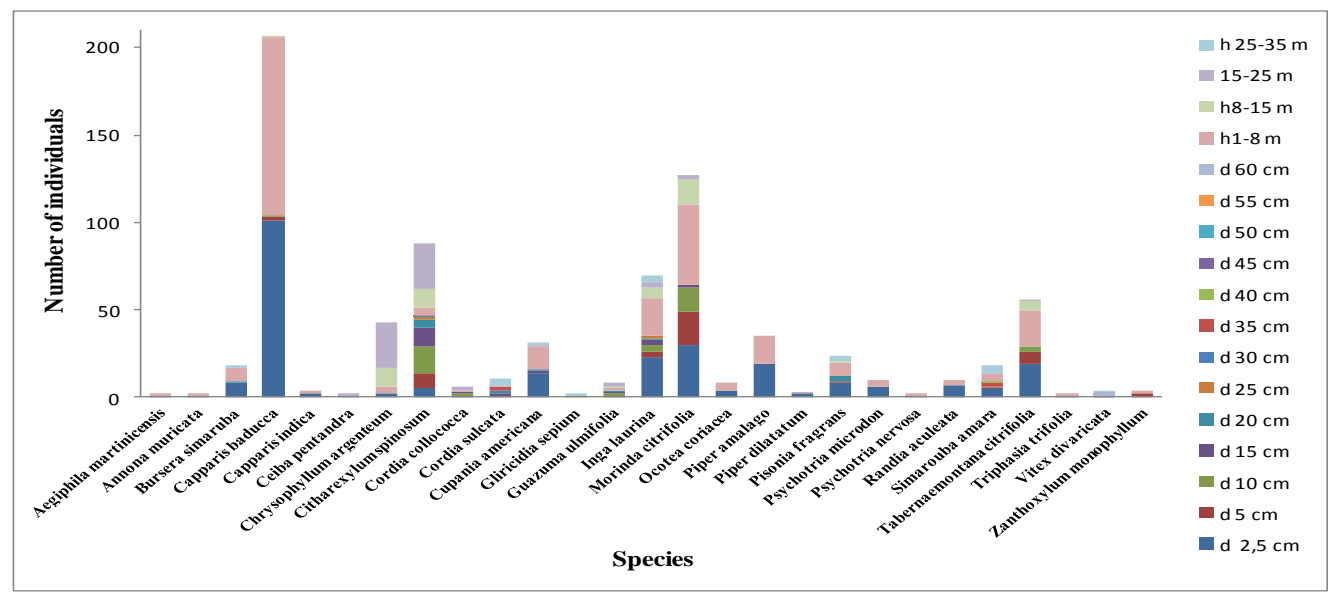

Figure 4: Diameter distribution (d) (diameters $\geq 2.5 \mathrm{~cm}$ ) and heights $(\mathrm{h})$ of live trees (heights $\geq 1 \mathrm{~m}$ )

\subsubsection{Station $2\left(500 \mathrm{~m}^{2}\right.$, Fig. 5)}

Table 2: Key Ecological and Structural Parameters

\begin{tabular}{|c|c|c|c|c|c|c|c|c|}
\hline Species & Family & Af & $\mathrm{Rf}$ & $\begin{array}{l}\text { Number of } \\
\text { individuals by } \\
\text { species excluding } \\
\text { regeneration }\end{array}$ & Density & $\begin{array}{l}\text { Distribution } \\
\text { Index }\end{array}$ & $\begin{array}{l}\text { Total } \\
\text { area } \\
\text { species }\end{array}$ & $\begin{array}{l}\text { Index of } \\
\text { Dominance }\end{array}$ \\
\hline $\begin{array}{l}\text { Capparis } \\
\text { baducca }\end{array}$ & Capparaceae & 5 & $100 \%$ & 259 & 0.518 & 0.518 & 0.1462062 & 0.07573483 \\
\hline $\begin{array}{l}\text { Simarouba } \\
\text { amara }\end{array}$ & Simaroubaceae & 4 & $80 \%$ & 25 & 0.05 & 0.04 & 1.53075 & 0.06123 \\
\hline Inga laurina & Mimosaceae & 4 & $80 \%$ & 62 & 0.124 & 0.0992 & 0.157 & 0.0155744 \\
\hline
\end{tabular}

Absolute frequency (Af): presence of the species in the different quadrats. / Relative frequency $($ Rf $)=$ Absolute frequency / number of quadrats / Density = number of individuals /survey area $/$ Distribution index $=$ Relative frequency $\times$ Density $/$ Dominance index $=$ Distribution index $\times$ Land surface $($ basal area $)$.

Evergreen tropical seasonal floristic formation in the unstructured young forest stage (undefined stratification). From an ecological point of view the predominant species are Capparis baducca and Simarouba amara, in addition to which we see a few Inga laurina individuals. Irrespective of their ecological status, the individuals of all species with a diameter ranging from 2.5 to $5 \mathrm{~cm}$ and a height of 1 to 8 meters form a dense floristic unit from which emerge adult specimens of Inga laurina and of Simarouba amara (Fig. 5). 


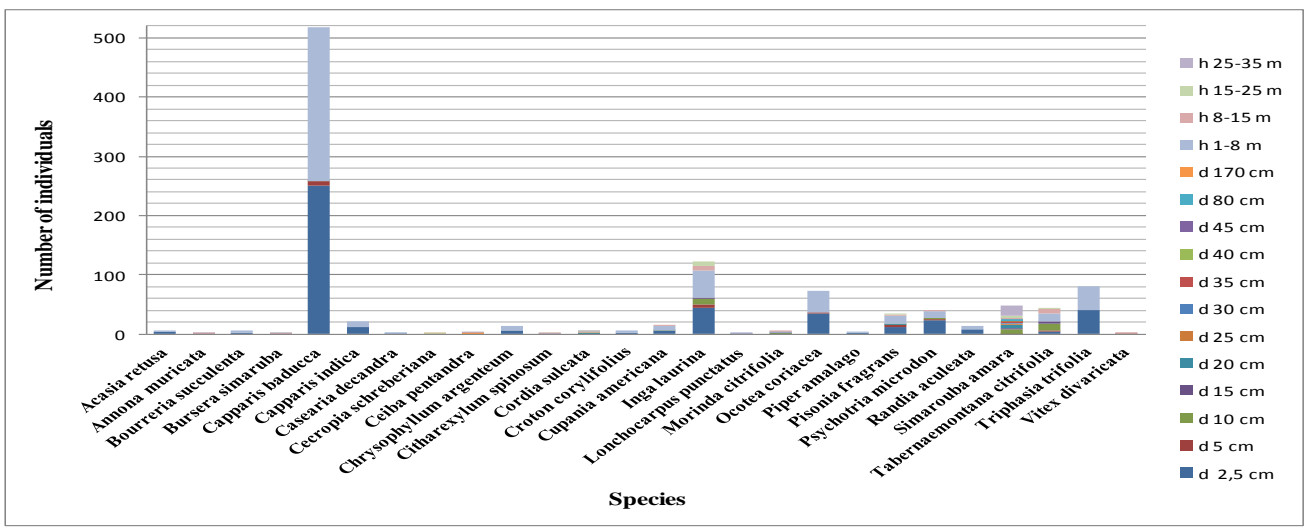

Figure 5: Diameter distribution (d) (diameters $\geq 2.5 \mathrm{~cm}$ ) and heights (h) of live trees (heights $\geq 1 \mathrm{~m}$ )

\subsubsection{Station $3\left(500 \mathrm{~m}^{2}\right.$, Fig. 6$)$}

Table 3 - Key Ecological and Structural Parameters

\begin{tabular}{|l|l|l|l|l|l|l|l|l|}
\hline Species & Family & Af & Rf & $\begin{array}{l}\text { Number of } \\
\text { individuals by } \\
\text { species } \\
\text { excluding } \\
\text { regeneration }\end{array}$ & Density & $\begin{array}{l}\text { Distribution } \\
\text { Index }\end{array}$ & $\begin{array}{l}\text { Total basal } \\
\text { area by species }\end{array}$ & $\begin{array}{l}\text { Index Dominance } \\
\text { Dof }\end{array}$ \\
\hline $\begin{array}{l}\text { Lonchocarpus } \\
\text { punctatus }\end{array}$ & Fabaceae & 5 & $100 \%$ & 25 & 0.05 & 0.05 & 0.47590625 & 0.02379531 \\
\hline $\begin{array}{l}\text { Citharexylum } \\
\text { spinosum }\end{array}$ & Verbenaceae & 5 & $100 \%$ & 21 & 0.042 & 0.042 & 0.46315 & 0.0194523 \\
\hline $\begin{array}{l}\text { Pisonia } \\
\text { fragrans }\end{array}$ & Nyctaginaceae & 5 & $100 \%$ & 95 & 0.19 & 0.19 & 0.08193437 & 0.01556753 \\
\hline
\end{tabular}

Absolute frequency (Af): presence of the species in the different quadrats. / Relative frequency $(R f)=$ Absolute frequency / number of quadrats $/$ Density $=$ number of individuals /survey area/ Distribution index $=$ Relative frequency $\times$ Density $/$ Dominance index $=$ Distribution inde $\times$ Land surface $($ basal area $)$.

Seasonal tropical evergreen (mesophilic) forest dominated by Lonchocarpus punctatus, Citharexylum spinosum and Pisonia fragrans. The first two species generally have a balanced biodemographic structure (Fig. 6): most age groups are represented. The population of the third species of the dominant population (Pisonia fragrans) essentially consists of stems with 2.5 centimetre diameters (Fig. 6). For this entire station, the majority of the heights range between 1 and 8 meters (Fig. 6).

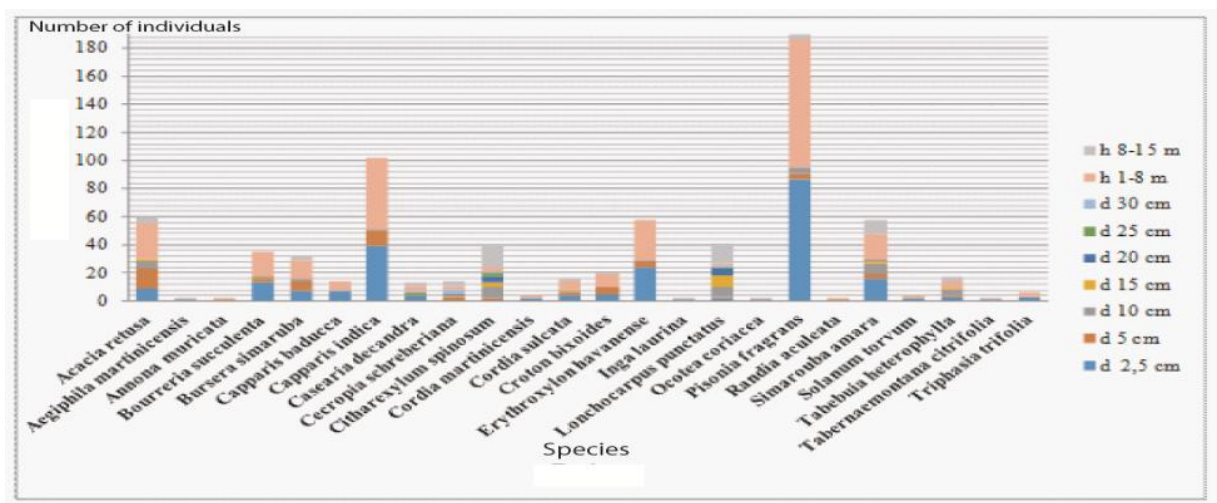

Figure 6: Diameter distribution (d) (diameters $\geq 2.5 \mathrm{~cm}$ ) and heights $(\mathrm{h})$ of live trees (heights $\geq 1 \mathrm{~m}$ )

4.1.4 Station $4\left(500 \mathrm{~m}^{2}\right.$, Fig. 7)

Table 4: Key Ecological and Structural Parameters

\begin{tabular}{|l|l|l|l|l|l|l|l|l|}
\hline Species & Family & Af & Rf & $\begin{array}{l}\text { Number of Density } \\
\text { individuals by } \\
\text { species } \\
\text { excluding } \\
\text { regeneration }\end{array}$ & $\begin{array}{l}\text { Distributio } \\
\mathrm{n} \text { Index }\end{array}$ & $\begin{array}{l}\text { Total } \\
\text { basal } \\
\text { area } \\
\text { species } \\
\text { by }\end{array}$ & $\begin{array}{l}\text { Index } \\
\text { dominance }\end{array}$ \\
\hline $\begin{array}{l}\text { Citharexylum } \\
\text { spinosum }\end{array}$ & Verbenaceae & 5 & $100 \%$ & 27 & 0.054 & 0.054 & 0.40427 & 0.02183085 \\
\hline Bursera & Burseraceae & 5 & $100 \%$ & 22 & 0.044 & 0.044 & 0.26248 & 0.01154931 \\
\hline
\end{tabular}


The effects of topography on Martinique's mesological and floristic differentiations: the case of

\begin{tabular}{|l|l|l|l|l|l|l|l|l|}
\hline simaruba & & & & & & & & \\
\hline $\begin{array}{l}\text { Lonchocarpus } \\
\text { punctatus }\end{array}$ & Fabaceae & 4 & $80 \%$ & 18 & 0.036 & 0.0288 & 0.26886 & 0.00774324 \\
\hline $\begin{array}{l}\text { Erythroxylon } \\
\text { havanense }\end{array}$ & $\begin{array}{l}\text { Erythroxylac } \\
\text { eae }\end{array}$ & 5 & $100 \%$ & 59 & 0.118 & 0.118 & 0.05544 & 0,00654199 \\
\hline
\end{tabular}

Absolute frequency (Af): presence of the species in the different quadrats. / Relative frequency $(R f)=$ Absolute frequency $/$ number of quadrats $/$ Density $=$ number of individuals $/$ survey area/ Distribution index $=$ Relative frequency $\times$ Density $/$ Dominance index $=$ Distribution inde $\times$ Land surface $($ basal area $)$.

Citharexylum spinosum, Bursera simaruba, Lonchocarpus punctatus and Erythroxylon havanense dominate this seasonal evergreen phytocenosis of lower horizon (xerophytic) and xeric facies (dry characteristics) in the young forest or even pre-forest stage for a small number of subunits (Fig. 7).

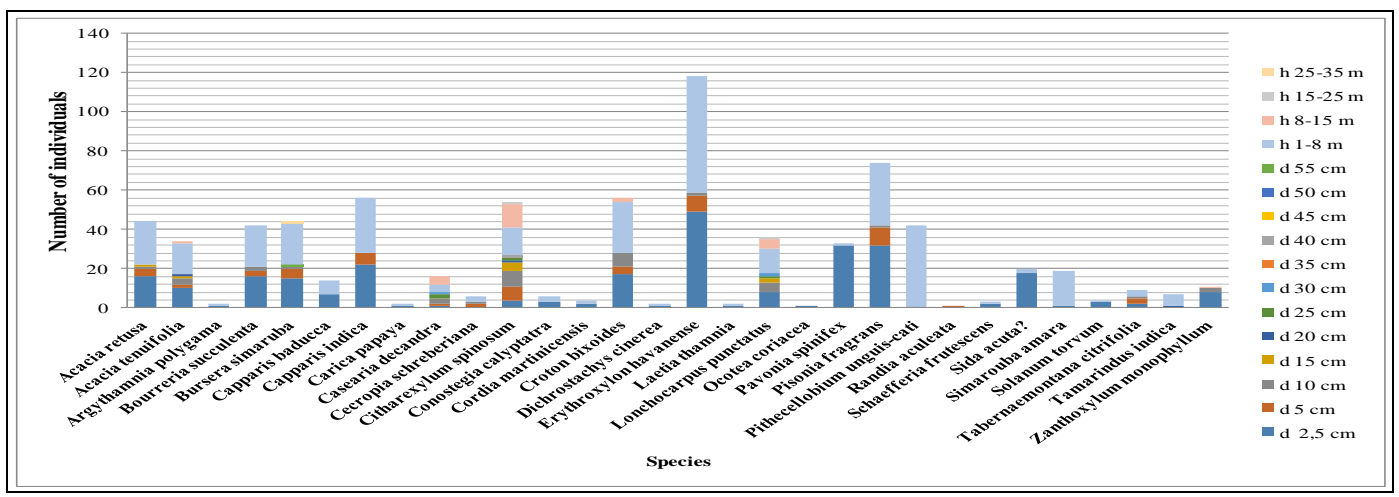

Figure 7: Diameter distribution (d) (diameters $\geq 2.5 \mathrm{~cm}$ ) and heights (h) of live trees (heights $\geq 1 \mathrm{~m}$ )

\subsubsection{Station $5\left(1000 \mathrm{~m}^{2}\right.$, Fig. 8)}

Table 5: Key Ecological and Structural Parameters

\begin{tabular}{|l|l|l|l|l|l|l|l|l|}
\hline Species & Family & Af & Rf & $\begin{array}{l}\text { Number of } \\
\text { individuals } \\
\text { by species } \\
\text { excluding } \\
\text { regeneration }\end{array}$ & Density & $\begin{array}{l}\text { Distribution } \\
\text { Index }\end{array}$ & $\begin{array}{l}\text { Total basal } \\
\text { area by species }\end{array}$ & $\begin{array}{l}\text { Index of } \\
\text { dominance }\end{array}$ \\
\hline $\begin{array}{l}\text { Citharexylum } \\
\text { spinosum }\end{array}$ & Verbenaceae & 9 & $90 \%$ & 78 & 0.078 & 0.0702 & 1.0342375 & 0.072603 \\
\hline $\begin{array}{l}\text { Pisonia } \\
\text { fragrans }\end{array}$ & Nyctaginaceae & 10 & $100 \%$ & 171 & 0.171 & 0.171 & 0.282109375 & 0.048240 \\
\hline $\begin{array}{l}\text { Simarouba } \\
\text { amara }\end{array}$ & Simaroubaceae & 10 & $100 \%$ & 81 & 0.081 & 0.081 & 0.157 & 0.012717 \\
\hline
\end{tabular}

Absolute frequency (Af): presence of the species in the different quadrats. / Relative frequency $(R f)=$ Absolute frequency $/$ number of quadrats $/$ Density $=$ number of individuals $/$ survey area/ Distribution index $=$ Relative frequency $\times$ Density $/$ Dominance index $=$ Distribution index $\times$ Land surface (basal area) .

Seasonal tropical evergreen (mesophilic) floristic formation dominated by Citharexylum spinosum and Pisonia fragrans. To this population we must add Simarouba amara. In fact, within this phytocenosis, these species are the most competing with regard to the mesological factors (environmental factors). Their adult individuals are numerically predominant in terms of diameters and heights, especially in relation to the upper stratum (Fig. 8).

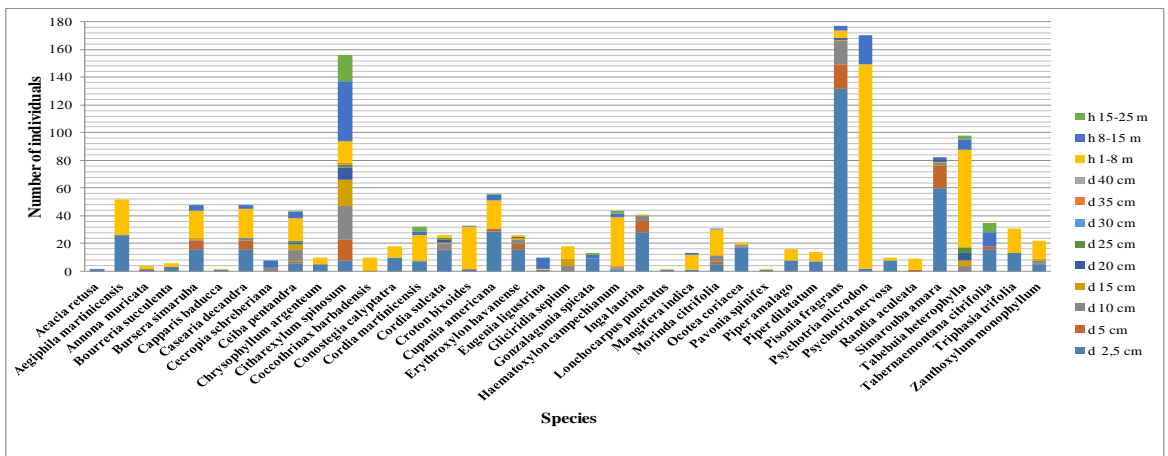

Figure 8: Diameter distribution (d) (diameters $\geq 2.5 \mathrm{~cm}$ ) and heights $(\mathrm{h})$ of live trees (heights $\geq 1 \mathrm{~m}$ ) 
The effects of topography on Martinique's mesological and floristic differentiations: the case of

4.1.6 Station $6\left(900 \mathrm{~m}^{2}\right.$, Fig. 9)

Table 6: Key Ecological and Structural Parameters

\begin{tabular}{|l|l|l|l|l|l|l|l|l|}
\hline Species & Family & Af & Rf & $\begin{array}{l}\text { Number of of } \\
\text { individuals by } \\
\text { species excluding } \\
\text { regeneration }\end{array}$ & Density & $\begin{array}{l}\text { Distribution } \\
\text { Index }\end{array}$ & $\begin{array}{l}\text { Total basal } \\
\text { area } \\
\text { by } \\
\text { species }\end{array}$ & $\begin{array}{l}\text { Index } \\
\text { Dominance }\end{array}$ \\
\hline $\begin{array}{l}\text { Citharexylum } \\
\text { spinosum }\end{array}$ & Verbenaceae & 9 & $100 \%$ & 131 & 0.1455 & 0.1455555 & 0.97046 & 0.114125 \\
\hline $\begin{array}{l}\text { Simarouba } \\
\text { amara }\end{array}$ & Simaroubaceae & 9 & $100 \%$ & 69 & 0.0767 & 0.0766666 & 0.28456 & 0.021816 \\
\hline $\begin{array}{l}\text { Tabernaemonta } \\
\text { na citrifolia }\end{array}$ & Apocynaceae & 9 & $100 \%$ & 112 & 0.1124 & 0.1124444 & 0.11338 & 0.014165 \\
\hline
\end{tabular}

Absolute frequency (Af): presence of the species in the different quadrats. / Relative frequency $($ Rf $)=$ Absolute frequency / number of quadrats / Density = number of individuals /survey area $/$ Distribution index $=$ Relative frequency $\times$ Density $/$ Dominance index $=$ Distribution index $\times$ Land surface $($ basal area $)$.

The species most likely to use environmental factors and therefore the most competitive are in order of importance: Citharexylum spinosum, Simarouba amara, Tabernaemontana citrifolia.Apart from Ceiba pentandra, Cordia sulcata and Samanea saman.The other species of this tropical seasonal evergreen (mesophilic) forest formation in the young forest or even pre-forest stage belong mainly to the 2.5 to $5 \mathrm{~cm}$ diametric classes and peak between 1 and 8 meters (Fig. 9).

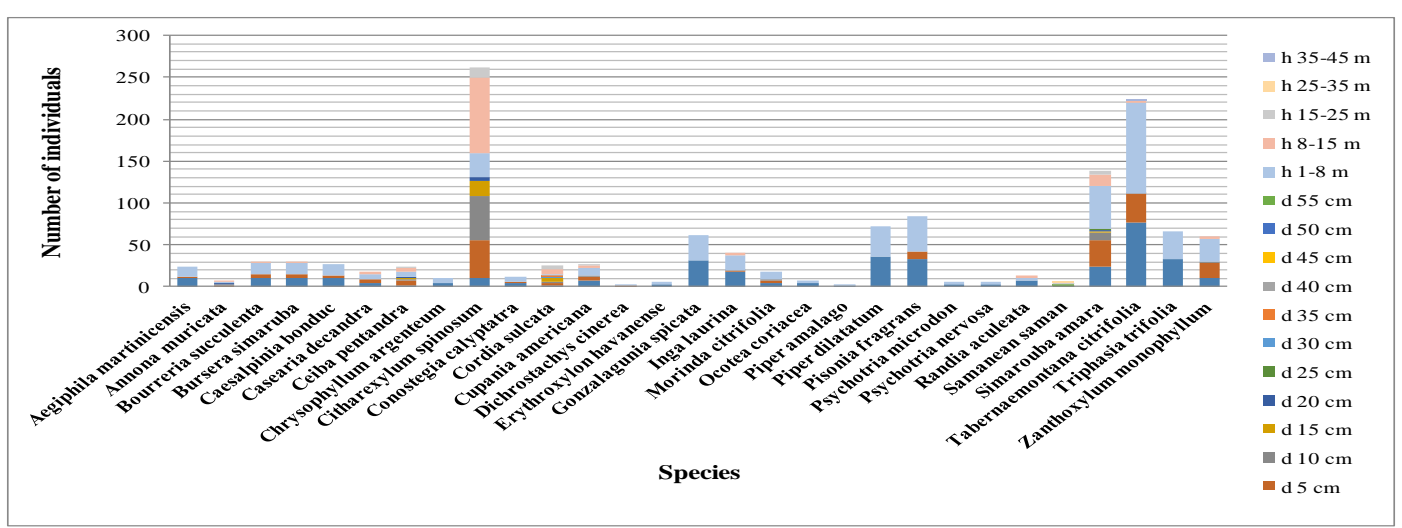

Figure 9: Diameter distribution (d) (diameters $\geq 2.5 \mathrm{~cm}$ ) and heights $(\mathrm{h})$ of live trees (heights $\geq 1 \mathrm{~m}$ )

\subsubsection{Station $7\left(1000 \mathrm{~m}^{2}\right.$, Fig. 10)}

Table 7: Key Ecological and Structural Parameters

\begin{tabular}{|l|l|l|l|l|l|l|l|l|}
\hline Species & Family & Af & Rf & $\begin{array}{l}\text { Number of Density } \\
\text { individuals by } \\
\text { species } \\
\text { excluding } \\
\text { regeneration }\end{array}$ & $\begin{array}{l}\text { Distributio } \\
\mathrm{n} \text { Index }\end{array}$ & $\begin{array}{l}\text { Total } \\
\text { basal } \\
\text { area } \\
\text { species } \\
\text { by }\end{array}$ & $\begin{array}{l}\text { Index } \\
\text { Dominance }\end{array}$ \\
\hline Pisonia fragrans & Nyctaginaceae & 9 & $90 \%$ & 134 & 0.134 & 0.1206 & 0.46021 & 0.05550087 \\
\hline $\begin{array}{l}\text { Haematoxylon } \\
\text { campechianum }\end{array}$ & Ceasalpiniaceae & 6 & $60 \%$ & 74 & 0.074 & 0.0444 & 0.51466 & 0.02285115 \\
\hline $\begin{array}{l}\text { Citharexylum } \\
\text { spinosum }\end{array}$ & Verbenaceae & 9 & $90 \%$ & 38 & 0.038 & 0.0342 & 0.24188 & 0.00827223 \\
\hline
\end{tabular}

Absolute frequency (Af): presence of the species in the different quadrats. / Relative frequency $(R f)=$ Absolute frequency / number of quadrats / Density = number of individuals /survey area/ Distribution index $=$ Relative frequency $\times$ Density $/$ Dominance index $=$ Distribution index $\times$ Land surface $($ basal area).

Lower horizon and xeric facies seasonal evergreen phytocenosis (xerophytic floristic formation) in the pre-forest or even young forest stage, from a biodemographic point of view and in order of importance dominated by Pisonia fragrans, Haematoxylon campechianum and Citharexylum spinosum. Apart from the latter, Cordia sulcata, Tabebuia heterophylla and Bursera simaruba have average sections and heights. The individuals of most other species range between 1 and 8 meters and have diameters between 2.5 and $5 \mathrm{~cm}$ (Fig. $10)$. 


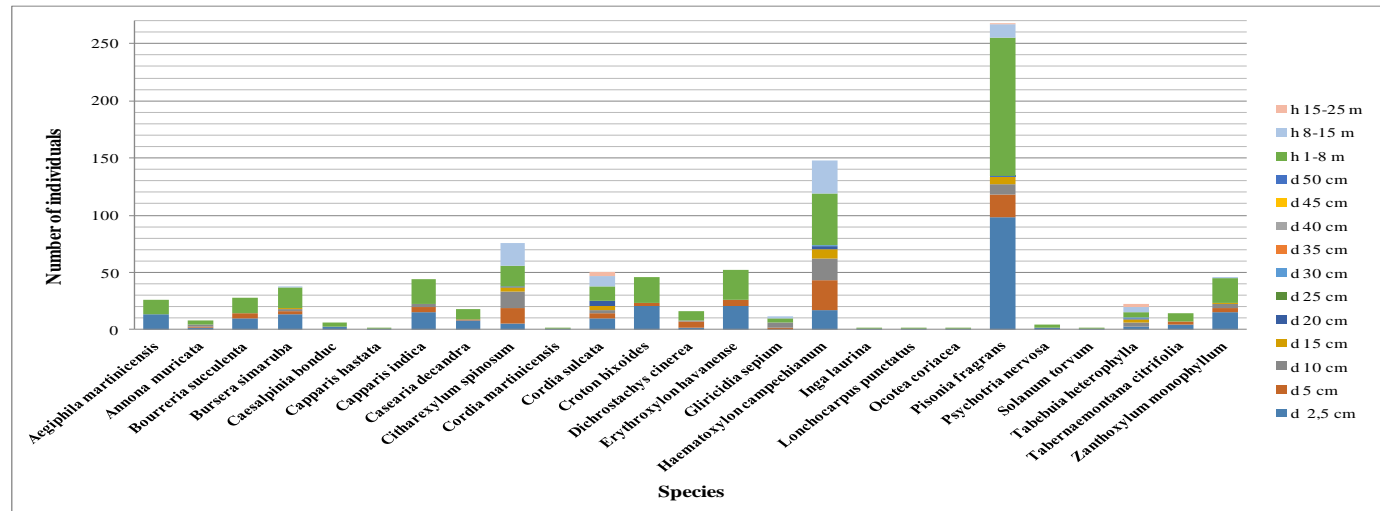

Figure 10: Diameter distribution (d) (diameters $\geq 2.5 \mathrm{~cm}$ ) and heights (h) of live trees (heights $\geq 1 \mathrm{~m}$ )

\subsubsection{Station $8\left(800 \mathrm{~m}^{2}\right.$, Fig. 11)}

Table 8: Key Ecological and Structural Parameters

\begin{tabular}{|l|l|l|l|l|l|l|l|l|}
\hline Species & Family & Af & Rf & $\begin{array}{l}\text { Number of } \\
\text { individuals by } \\
\text { species } \\
\text { excluding } \\
\text { regeneration }\end{array}$ & Density & $\begin{array}{l}\text { Distributio } \\
\text { n Index }\end{array}$ & $\begin{array}{l}\text { Total } \\
\text { basal } \\
\text { area by } \\
\text { species }\end{array}$ & $\begin{array}{l}\text { Index of } \\
\text { Dominance }\end{array}$ \\
\hline $\begin{array}{l}\text { Inga laurina } \\
\text { sordia }\end{array}$ & Mimosaceae & 8 & $100 \%$ & 86 & 0.1075 & 0.1075 & 0.59169 & 0.06360708 \\
\hline
\end{tabular}

Absolute frequency (Af): presence of the species in the different quadrats. / Relative frequency $(R f)=$ Absolute frequency / number of quadrats $/$ Density $=$ number of individuals /survey area/ Distribution index $=$ Relative frequency $\times$ Density $/$ Dominance index $=$ Distribution index $\times$ Land surface $($ basal area $)$.

Tropical evergreen seasonal floristic unit in the unstructured young forest stage.From an ecological point of view Inga laurina and Cordia sulcata are the two species most likely to use the mesological factors (environmental factors). However, in order to complete this prevailing cortege, Citharexylum spinosum and Tabernaemontana citrifolia. Citharexylum spinosum, Cordia sulcata and Inga laurina have a fairly balanced demographic structure: the individuals are present in several diametric and height classes (Fig. 11).

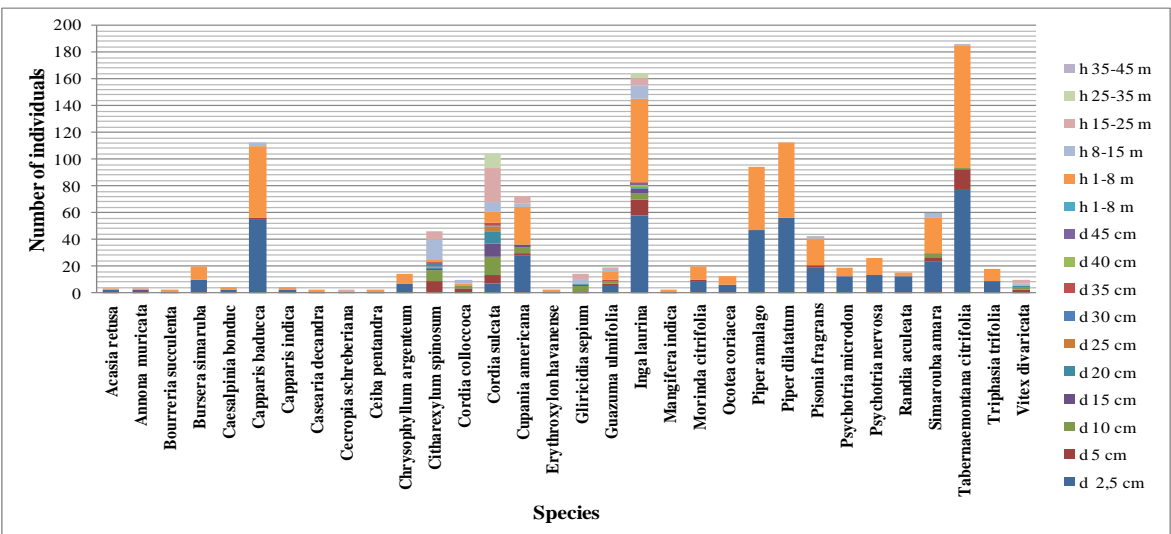

Figure 11: Diameter distribution (d) (diameters $\geq 2.5 \mathrm{~cm}$ ) and heights (h) of live trees (heights $\geq 1 \mathrm{~m}$ )

\subsubsection{Station $9\left(500 \mathrm{~m}^{2}\right.$, Fig. 12)}

Table 9: Key Ecological and Structural Parameters

\begin{tabular}{|l|l|l|l|l|l|l|l|l|}
\hline Species & Family & Af & Rf & $\begin{array}{l}\text { Number of } \\
\text { individuals } \\
\text { by species } \\
\text { excluding } \\
\text { regeneration }\end{array}$ & Density & $\begin{array}{l}\text { Distribution } \\
\text { Index }\end{array}$ & $\begin{array}{l}\text { Total basal } \\
\text { area } \\
\text { by species }\end{array}$ & $\begin{array}{l}\text { Index of } \\
\text { Dominance }\end{array}$ \\
\hline $\begin{array}{l}\text { Pisonia } \\
\text { fragrans }\end{array}$ & Nyctaginaceae & 5 & $100 \%$ & 132 & 0.264 & 0.264 & 0.1712281 & 0.04520423 \\
\hline $\begin{array}{l}\text { Bursera } \\
\text { simarouba }\end{array}$ & Burseraceae & 3 & $60 \%$ & 9 & 0.018 & 0.0108 & 1.055825 & 0.01140291 \\
\hline
\end{tabular}


The effects of topography on Martinique's mesological and floristic differentiations: the case of

Absolute frequency $(A f)$ : presence of the species in the different quadrats. / Relative frequency $(R f)=$ Absolute frequency / number of quadrats / Density = number of individuals /survey area/ Distribution index $=$ Relative frequency $\times$ Density $/$ Dominance index $=$ Distribution index $\times$ Land surface $($ basal area $)$.

Within this seasonal tropical evergreen secondary forest formation Pisonia fragrans and Bursera simarouba are the two species with significant ecologically significant Indices of Dominance. However, their biodemographic structures are different, since the first species' individuals are distributed, at various densities, in all diameter classes ranging between 2.5 and $20 \mathrm{~cm}$, while those (individuals) of the second species have sections ranging from 30 to $50 \mathrm{~cm}$ (Fig. 12). It is clear that the Bursera simarouba population is composed only of adult trees in morphogenetic expansion (in development). This species does not regenerate, unlike Pisonia fragrans which is characterized by a balanced population. Mature specimens of Pisonia fragrans, Bursera simarouba and Citharexylum spinosum occupy the upper stratum and form a canopy with non-interlocking crowns (Figure 12).

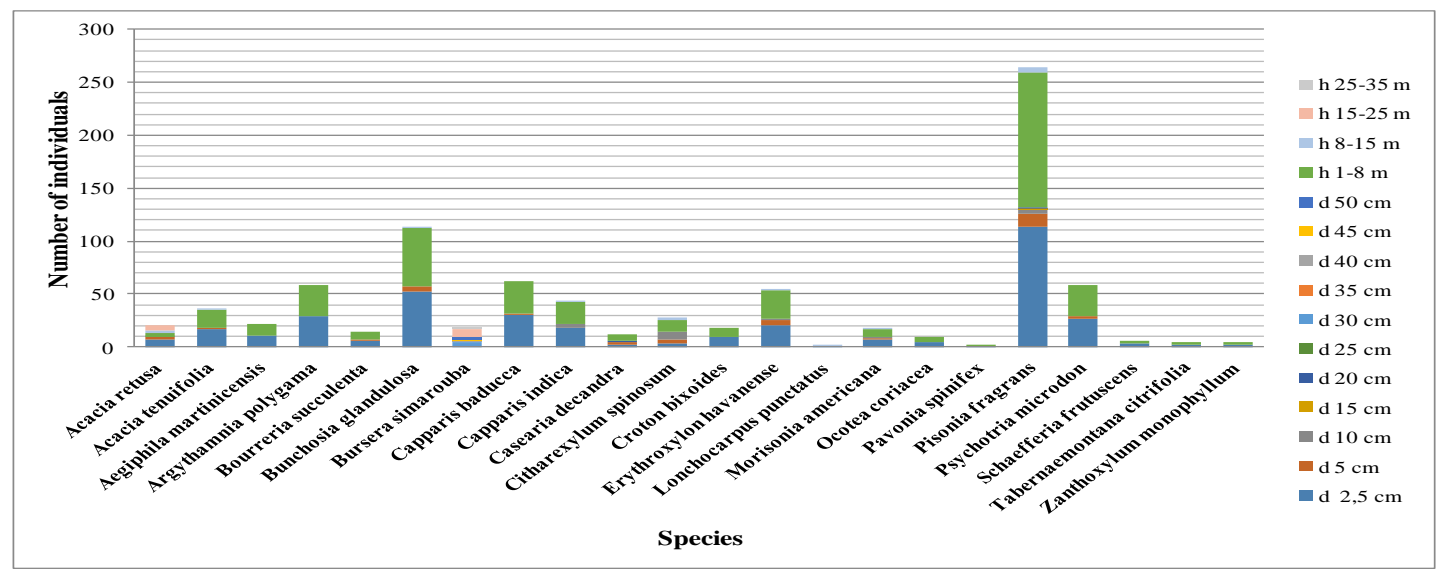

Figure 12: Diameter distribution (d) (diameters $\geq 2.5 \mathrm{~cm}$ ) and heights (h) of live trees (heights $\geq 1 \mathrm{~m}$ )

\subsubsection{Station $10\left(700 \mathrm{~m}^{2}\right.$, Fig. 13)}

Table 10 : Key Ecological and Structural Parameters

\begin{tabular}{|l|l|l|l|l|l|l|l|l|}
\hline Species & Family & Af & Rf & $\begin{array}{l}\text { Number of } \\
\text { individuals by } \\
\text { species } \\
\text { excluding } \\
\text { regeneration }\end{array}$ & Density & $\begin{array}{l}\text { Distributio } \\
\text { n Index }\end{array}$ & $\begin{array}{l}\text { Total } \\
\text { basal area } \\
\text { by } \\
\text { species }\end{array}$ & $\begin{array}{l}\text { Index } \\
\text { Dominance }\end{array}$ \\
\hline Inga laurina & Mimosaceae & 7 & $100 \%$ & 83 & 0,11857 & 0,11857143 & 0.59807 & 0.07091424 \\
\hline $\begin{array}{l}\text { Capparis } \\
\text { baducca }\end{array}$ & Capparaceae & 7 & $100 \%$ & 152 & 0.21714 & 0.21714286 & 0.08488 & 0.01843068 \\
\hline $\begin{array}{l}\text { Citharexylum } \\
\text { spinosum }\end{array}$ & Verbenaceae & 5 & $71 \%$ & thirty & 0.04286 & 0.03061224 & 0.58286 & 0.01784273 \\
\hline Cordia sulcata & Boraginaceae & 4 & $57 \%$ & 16 & 0.02286 & 0.01306122 & 0.21097 & 0.00275551 \\
\hline
\end{tabular}

Absolute frequency: presence of the species in the different quadrats. / Relative frequency $=$ Absolute frequency $/$ number of quadrats / Density $=$ number of individuals /survey area/ Distribution index $=$ Relative frequency $\times$ Density $/$ Dominance index $=$ Distribution index $\times$ Land surface (basal area).

This tropical seasonal evergreen young forest phytocenosis is dominated by Inga Laurina which presents a balanced biodemographic profile: the individuals are distributed in almost all diameter classes. However, in order of importance, the preponderant population can be considered to consist of three species: Inga Laurina, Capparis baducca and Citharexylum spinosum. Although Capparis baducca individuals barely surpass five centimeters in diameter, the latter's biographical profile and that of Citharexylum spinosum are also balanced. In general, the individuals of the 2.5 to 5 centimeter classes of mature or morphogenetic (developing) species constitute a floristic matrix (the lower stratum) from which emerge adult trees whose diameters and heights respectively range between 15 and $80 \mathrm{~cm}$ and between 8 and $25 \mathrm{~m}$ (Fig. 13). 


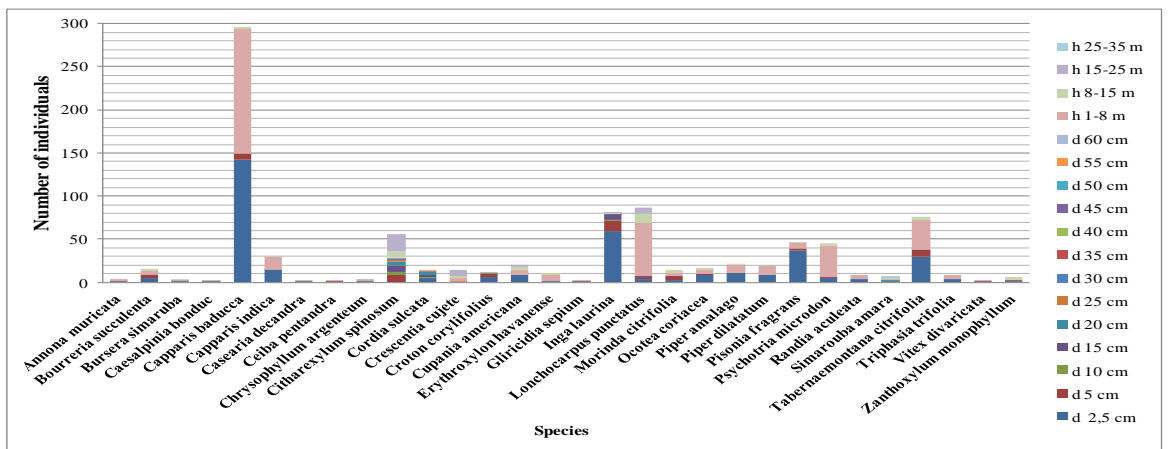

Figure 13: Diameter distribution (d) (diameters $\geq 2.5 \mathrm{~cm}$ ) and heights (h) of live trees (heights $\geq 1 \mathrm{~m}$ )

\subsubsection{Station $11\left(500 \mathrm{~m}^{2}\right.$, Fig. 14)}

Table 11: Key Ecological and Structural Parameters

\begin{tabular}{|l|l|l|l|l|l|l|l|l|}
\hline Species & Family & Af & Rf & $\begin{array}{l}\text { Number of } \\
\text { individuals by } \\
\text { species excluding } \\
\text { regeneration }\end{array}$ & Density & $\begin{array}{l}\text { Distribution } \\
\text { Index }\end{array}$ & $\begin{array}{l}\text { Total basal } \\
\text { area by } \\
\text { species }\end{array}$ & $\begin{array}{l}\text { Index of } \\
\text { Dominance }\end{array}$ \\
\hline $\begin{array}{l}\text { Croton } \\
\text { corylifolius }\end{array}$ & Euphorbiaceae & 4 & $80 \%$ & 85 & 0.17 & 0.136 & 0.184475 & 0.0250886 \\
\hline
\end{tabular}

Absolute frequency (Af): presence of the species in the different quadrats. / Relative frequency $(R f)=$ Absolute frequency / number of quadrats $/$ Density $=$ number of individuals /survey area/ Distribution index $=$ Relative frequency $\times$ Density $/$ Dominance index $=$ Distribution index $\times$ Land surface $($ basal area $)$.

Tropical seasonal evergreen forest of lower horizon and xeric facies [xerophytic (dry) formation] in the pre-forest stage strongly dominated by Croton corylifolius. Most individuals have small diameters (between 2.5 and $5 \mathrm{~cm}$ ) and are not high (heights between 1 and $8 \mathrm{~m}$ ) and form a rather dense structure surpassed by Croton corylifolius, Pisonia fragrans, Ocotea coriacea and Citharexylum spinosum adults (Fig. 14). The biographical profileof Ocotea coriacea is balanced, in spite of the individuals' low density per diametric class (Fig. 14). This species settles in the post-pioneer phases and is perennial in the climax phases of the formations influenced by the dry bioclimate.

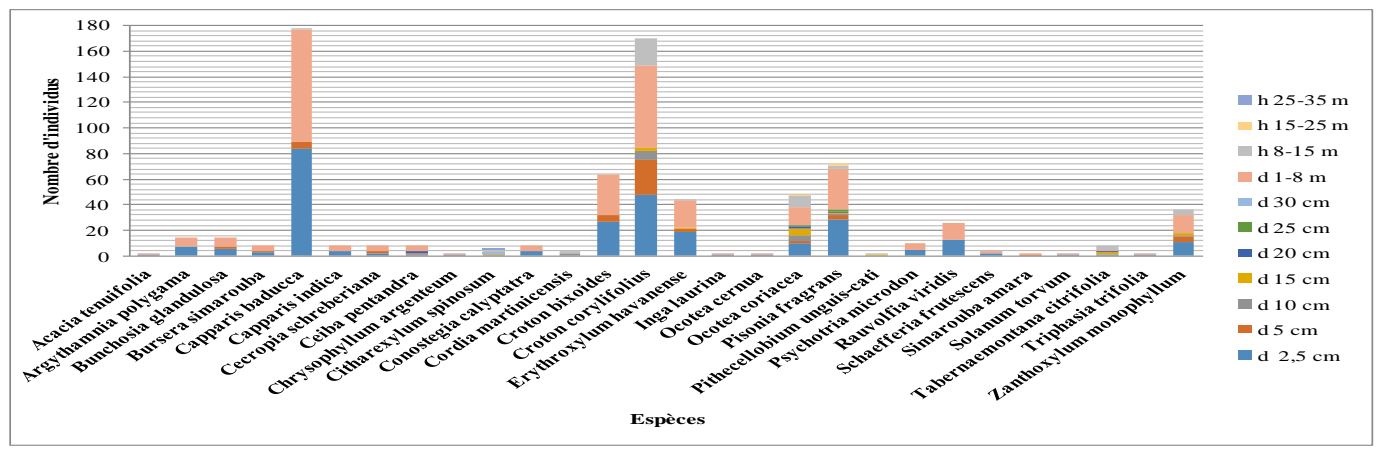

Figure 14: Diameter distribution (d) (diameters $\geq 2.5 \mathrm{~cm}$ ) and heights (h) of live trees (heights $\geq 1 \mathrm{~m}$ )

4.1.12Station $12\left(700 \mathrm{~m}^{2}\right.$, Fig. 15)

Table 12: Key Ecological and Structural Parameters

\begin{tabular}{|l|l|l|l|l|l|l|l|l|}
\hline Species & Family & Af & Rf & $\begin{array}{l}\text { Number of } \\
\text { individuals } \\
\text { by species } \\
\text { excluding } \\
\text { regeneration }\end{array}$ & Density & $\begin{array}{l}\text { Distribution } \\
\text { Index }\end{array}$ & $\begin{array}{l}\text { Total } \\
\text { area } \\
\text { species }\end{array}$ & $\begin{array}{c}\text { basal } \\
\text { by }\end{array}$ \\
\hline $\begin{array}{l}\text { Pisonia } \\
\text { fragrans }\end{array}$ & Nyctaginaceae & 7 & $100 \%$ & 217 & 0.31 & 0.31 & 0.2374625 & 0.073613375 \\
\hline $\begin{array}{l}\text { Lonchocarpus } \\
\text { punctatus }\end{array}$ & Fabaceae & 6 & $86 \%$ & 26 & 0.03714286 & 0.03183673 & 1.01215938 & 0.03222385 \\
\hline $\begin{array}{l}\text { Bursera } \\
\text { simaruba }\end{array}$ & Burseraceae & 7 & $100 \%$ & 29 & 0.04142857 & 0.04142857 & 0.70355625 & 0.02914733 \\
\hline $\begin{array}{l}\text { Citharexylum } \\
\text { spinosum }\end{array}$ & Verbenaceae & 5 & $71 \%$ & 58 & 0.08285714 & 0.05918367 & 0.119134375 & 0.011324426 \\
\hline $\begin{array}{l}\text { Bourreria } \\
\text { succulenta }\end{array}$ & Boraginaceae & 7 & $100 \%$ & 73 & 0.10428571 & 0.10428571 & 0,09567187 & 0.00997721 \\
\hline
\end{tabular}


The effects of topography on Martinique's mesological and floristic differentiations: the case of

Absolute frequency $(A f)$ : presence of the species in the different quadrats. / Relative frequency $(R f)=$ Absolute frequency / number of quadrats / Density = number of individuals /survey area/ Distribution index $=$ Relative frequency $\times$ Density $/$ Dominance index $=$ Distribution index $\times$ Land surface $($ basal area).

In order of importance and with regard to variations in relative frequency, density and basal area, the most competing species of this pre-forest floristic group or those best able to use the mesological factors (environmental factors) are Pisonia fragrans, Lonchocarpus punctatus, Bursera simaruba, Citharexylum spinosum and Bourreria succulenta. The fact that the species with a small number of large diameter individuals participate in the ecologically predominant population shows the secondary character of this phytocenosis. This is the case of Bursera simaruba. The majority of its sections fall in the $2.5 \mathrm{~cm}$ class, which corresponds to low height stems (Fig. 15).

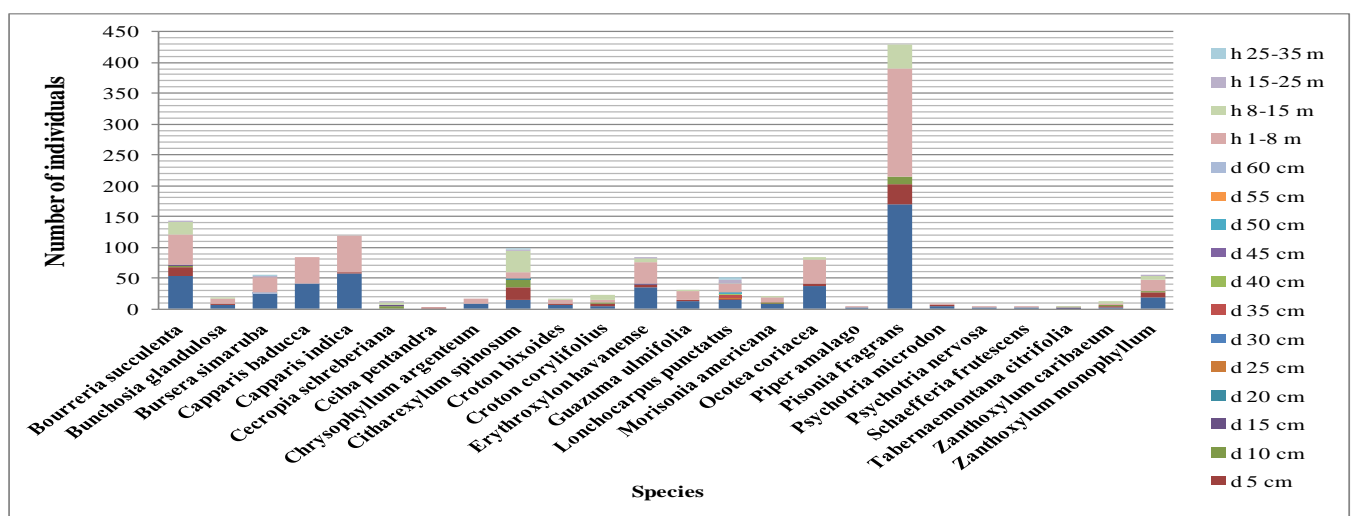

Figure 15: Diameter distribution (d) (diameters $\geq 2.5 \mathrm{~cm}$ ) and heights $(\mathrm{h})$ of live trees (heights $\geq 1 \mathrm{~m}$ )

\subsubsection{Station $13\left(1000 \mathrm{~m}^{2}\right.$, Fig. 16)}

Table 13: Key Ecological and Structural Parameters

\begin{tabular}{|l|l|l|l|l|l|l|l|l|}
\hline Species & Family & Af & Rf & $\begin{array}{l}\text { Number of of } \\
\text { individuals by } \\
\text { species excluding } \\
\text { regeneration }\end{array}$ & Density & $\begin{array}{l}\text { Distribution } \\
\text { Index }\end{array}$ & $\begin{array}{l}\text { Total } \\
\text { basal } \\
\text { area } \\
\text { species } \\
\text { by }\end{array}$ & $\begin{array}{l}\text { Index Dominance } \\
\text { of }\end{array}$ \\
\hline $\begin{array}{l}\text { Pisonia } \\
\text { fragrans }\end{array}$ & Nyctaginaceae & 10 & $100 \%$ & 271 & 0.271 & 0.271 & 0.43322 & 0,11740313 \\
\hline $\begin{array}{l}\text { Croton } \\
\text { corylifolius }\end{array}$ & Euphorbiaceae & 10 & $100 \%$ & 116 & 0.116 & 0.116 & 0.21587 & 0.0250415 \\
\hline $\begin{array}{l}\text { Morisonia } \\
\text { americana }\end{array}$ & Capparaceae & 9 & $90 \%$ & 176 & 0.176 & 0.1584 & 0.10401 & 0.01647558 \\
\hline
\end{tabular}

Absolute frequency: presence of the species in the different quadrats. / Relative frequency = Absolute frequency / number of quadrats / Density $=$ number of individuals /survey area/ Distribution index $=$ Relative frequency $\times$ Density $/$ Dominance index $=$ Distribution index $\times$ Land surface $($ basal area) .

Pisonia fragrans is the best distributed species of this evergreen tropical seasonal floristic formation in the young forest stage. HoweverCroton corylifolius and Morisonia americana complete the dominant population. These three species are the most competing and structure this survey station. The diameter and heights classes of small dimensions are the best represented $(2.5 \mathrm{~cm}$ for the diameters and between 1 and $8 \mathrm{~m}$ for the heights, Fig. 16).

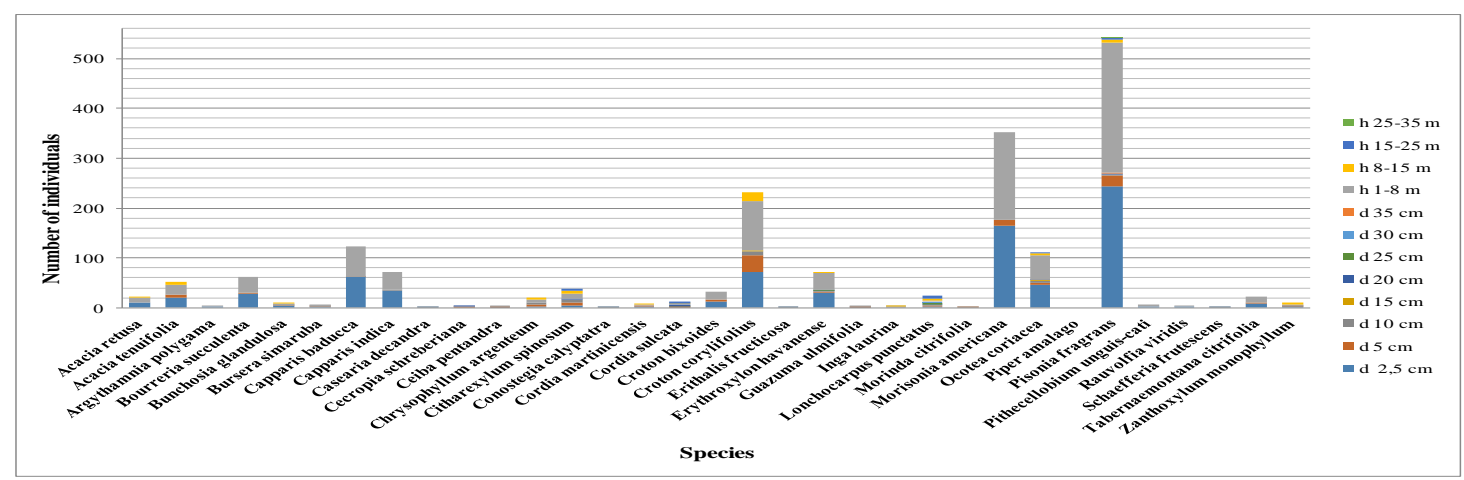

Figure 16: Diameter distribution (d) (diameters $\geq 2.5 \mathrm{~cm}$ ) and heights (h) of live trees (heights $\geq 1 \mathrm{~m}$ ) 
The effects of topography on Martinique's mesological and floristic differentiations: the case of

\subsubsection{Station $14\left(800 \mathrm{~m}^{2}\right.$, Fig. 17)}

Table 14: Key Ecological and Structural Parameters

\begin{tabular}{|l|l|l|l|l|l|l|l|l|}
\hline Species & Family & Af & Rf & $\begin{array}{l}\text { Number of } \\
\text { individuals } \\
\text { by species } \\
\text { excluding } \\
\text { regeneration }\end{array}$ & Density & $\begin{array}{l}\text { Distribution } \\
\text { Index }\end{array}$ & $\begin{array}{l}\text { Total } \\
\text { basal } \\
\text { area by } \\
\text { species }\end{array}$ & $\begin{array}{l}\text { Index of } \\
\text { Dominance }\end{array}$ \\
\hline $\begin{array}{l}\text { Pisonia } \\
\text { fragrans }\end{array}$ & Nyctaginaceae & 8 & $100 \%$ & 133 & 0.1625 & 0.1625 & 1,11176 & 0.18482948 \\
\hline $\begin{array}{l}\text { Ocotea } \\
\text { coriacea }\end{array}$ & Lauraceae & 8 & $100 \%$ & 192 & 0.24 & 0.24 & 0.39446 & 0.094671 \\
\hline $\begin{array}{l}\text { Morisonia } \\
\text { americana }\end{array}$ & Capparaceae & 7 & $88 \%$ & 125 & 0.15625 & 0.13671875 & 0.10401 & 0.01422046 \\
\hline $\begin{array}{l}\text { Capparis } \\
\text { baducca }\end{array}$ & Capparaceae & 8 & $100 \%$ & 125 & 0.15625 & 0.15625 & 0.089293 & 0.01395215 \\
\hline
\end{tabular}

Absolute frequency (Af): presence of the species in the different quadrats. / Relative frequency $(R f)=$ Absolute frequency $/$ number of quadrats $/$ Density $=$ number of individuals $/$ survey area/ Distribution index $=$ Relative frequency $\times$ Density $/$ Dominance index $=$ Distribution index $\times$ Land surface (basal area) .

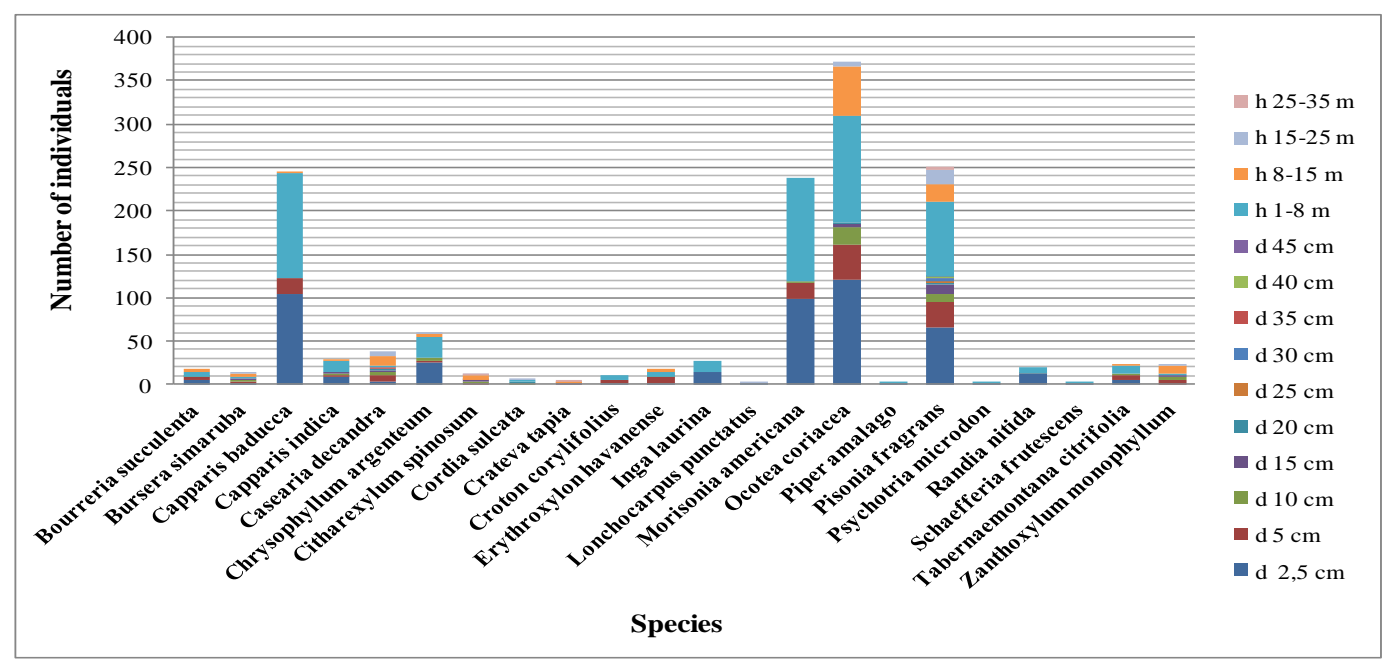

Figure 17: Diameter distribution (d) (diameters $\geq 2.5 \mathrm{~cm}$ ) and heights (h) of live trees (heights $\geq 1 \mathrm{~m}$ )

Pisonia fragrans and Ocotea coriacea have the highest indices of dominance. Therefore these species represent the dominant population in terms of their ability to use the biotope factors linked to this floristic surveys station. This corresponds to an evergreen tropical (mesophilic) seasonal vegetation in the young forest stage. To complement the dominant population, we must also add Morisonia americana and Capparis baducca, both of which have a significant Distribution Index and a low basal area, indicating that the majority of sections falls in the $2.5 \mathrm{~cm}$ and $5 \mathrm{~cm}$ classes (Fig. 17). Apart from certain Pisonia fragrans, Ocotea coriacea and Casearia decandra individuals, the majority of the stems have heights not exceeding $15 \mathrm{~m}$ (Fig. 17). In order of importance, infrequent species such as Randia nitida, Cissampelos pareira and Cupania americana are poorly distributed and have negligible biomass. This poses the problem of their true perpetuity.

\subsubsection{Station $15\left(1000 \mathrm{~m}^{2}\right.$, Fig. 18$)$}

Table 15: Key Ecological and Structural Parameters

\begin{tabular}{|l|l|l|l|l|l|l|l|l|}
\hline Species & Family & Af & Rf & $\begin{array}{l}\text { Number of } \\
\text { individuals by } \\
\text { species } \\
\text { excluding } \\
\text { regeneration }\end{array}$ & Density & $\begin{array}{l}\text { Distribution } \\
\text { Index }\end{array}$ & $\begin{array}{l}\text { Total } \\
\text { basal area } \\
\text { by } \\
\text { species }\end{array}$ & $\begin{array}{l}\text { Index of } \\
\text { Dominance }\end{array}$ \\
\hline $\begin{array}{l}\text { Cordia } \\
\text { sulcata }\end{array}$ & Boraginaceae & 10 & $100 \%$ & 125 & 0.125 & 0.125 & 0.91011 & 0.11137637 \\
\hline $\begin{array}{l}\text { Mangifera } \\
\text { indica }\end{array}$ & Anacardiaceae & 10 & $100 \%$ & 28 & 0.028 & 0.028 & 0.90962 & 0.02546932 \\
\hline
\end{tabular}

Absolute frequency (Af): presence of the species in the different quadrats. / Relative frequency $(R f)=$ Absolute frequency / number of quadrats / Density = number of individuals /survey area/ Distribution index $=$ Relative frequency $\times$ Density $/$ Dominance index $=$ Distribution index $\times$ Land surface $($ basal area) . 
Due to its balanced biodemographic profile and strong distribution Cordia sulcata dominates this tropical seasonal (mesophilic) evergreen phytocenosis in the young, poorly structured forest stage or even in the pre-forest stage. In fact, the regenerations of the upper stratum species and the lower stratum adults form a dense unit from which emerge mature Cordia sulcata, Cecropia schreberiana, Mangifera indica and Simarouba amara individuals. In general, the sections as well as the heights are small (Fig. 18). Randia nitida and Cissampelos will pareira are ecologically insignificant.

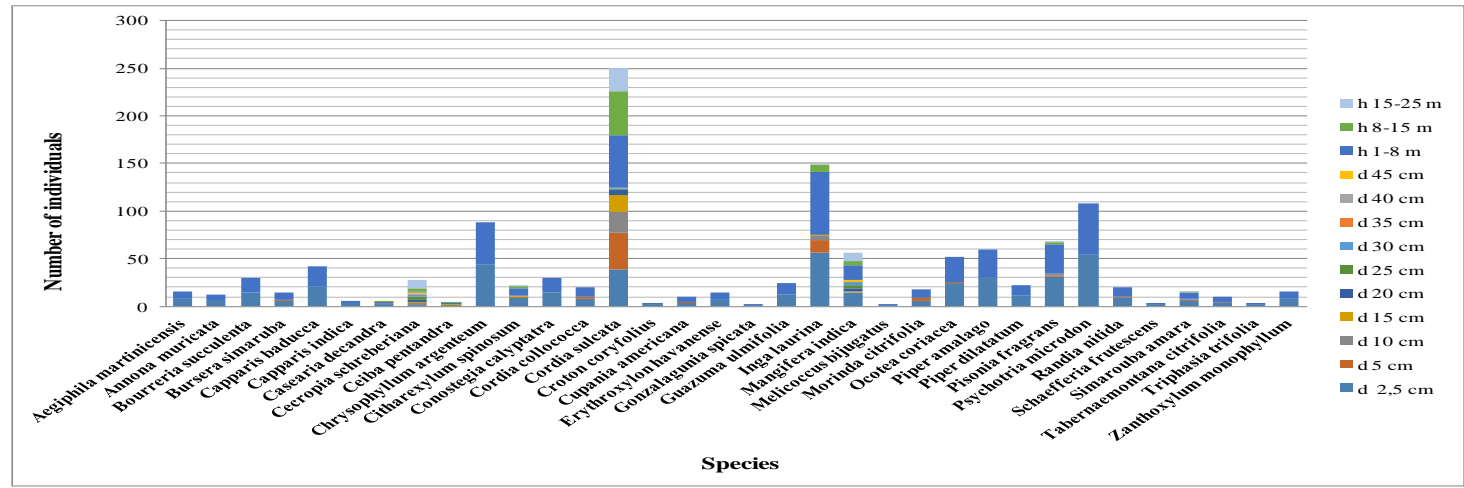

Figure 18: Diameter distribution (d) (diameters $\geq 2.5 \mathrm{~cm}$ ) and heights (h) of live trees (heights $\geq 1 \mathrm{~m}$ )

\subsubsection{Station $16\left(850 \mathrm{~m}^{2}\right.$, Fig. 19)}

Table 16: Key Ecological and Structural Parameters

\begin{tabular}{|c|c|c|c|c|c|c|c|c|}
\hline Species & Family & Af & $\operatorname{Rf}$ & $\begin{array}{l}\text { Number of } \\
\text { individuals } \\
\text { by species } \\
\text { excluding } \\
\text { regeneration }\end{array}$ & Density & $\begin{array}{l}\text { Distribution } \\
\text { Index }\end{array}$ & $\begin{array}{l}\text { Total basal } \\
\text { area by } \\
\text { species }\end{array}$ & $\begin{array}{l}\text { Index of } \\
\text { Dominance }\end{array}$ \\
\hline Ocotea coriacea & Lauraceae & 10 & $100 \%$ & 224 & 0.26353 & 0.26352941 & 0.25218 & 0.0664576 \\
\hline $\begin{array}{l}\text { Tabernaemontana } \\
\text { citrifolia }\end{array}$ & Apocynaceae & 10 & $100 \%$ & 78 & 0.09176 & 0.09176471 & 0.18202 & 0.01670318 \\
\hline Croton corylifolius & Euphorbiaceae & 9 & $90 \%$ & 74 & 0.08706 & 0.07835294 & 0.20459 & 0.01603028 \\
\hline Inga laurina & Mimosaceae & 9 & $90 \%$ & 92 & 0.10823529 & 0.09741176 & 0.14915 & 0.01452896 \\
\hline Pisonia fragrans & Nyctaginaceae & 10 & $100 \%$ & 26 & 0.03059 & 0.03058824 & 0.42439063 & 0.01298136 \\
\hline $\begin{array}{l}\text { Chrysophyllum } \\
\text { argenteum }\end{array}$ & Sapotaceae & 10 & $100 \%$ & 76 & 0,08941 & 0,08941176 & 0.11873 & 0.01061597 \\
\hline
\end{tabular}

Absolute frequency $(A f)$ : presence of the species in the different quadrats. / Relative frequency $(R f)=$ Absolute frequency / number of quadrats / Density $=$ number of individuals /survey area/ Distribution index $=$ Relative frequency $\times$ Density $/$ Dominance index $=$ Distribution inde $\times$ Land surface $($ basal area $)$.

Within this young barely structured forest, evergreen tropical seasonal (mesophilic) floristic community, Ocotea coriacea is highly competitive. With the latter and in order of importance with regard to the Dominance Index (Table 16), Tabernaemontana citrifolia, Croton corylifolius, Inga laurina, Pisonia fragrans and Chrysophyllum argenteum constitute the preponderant population from an ecological point of view. Individuals of small sizes and low land surfaces predominate (Fig. 19). Randia nitida (rare species) has been recorded; however, this species has little ecological importance here.

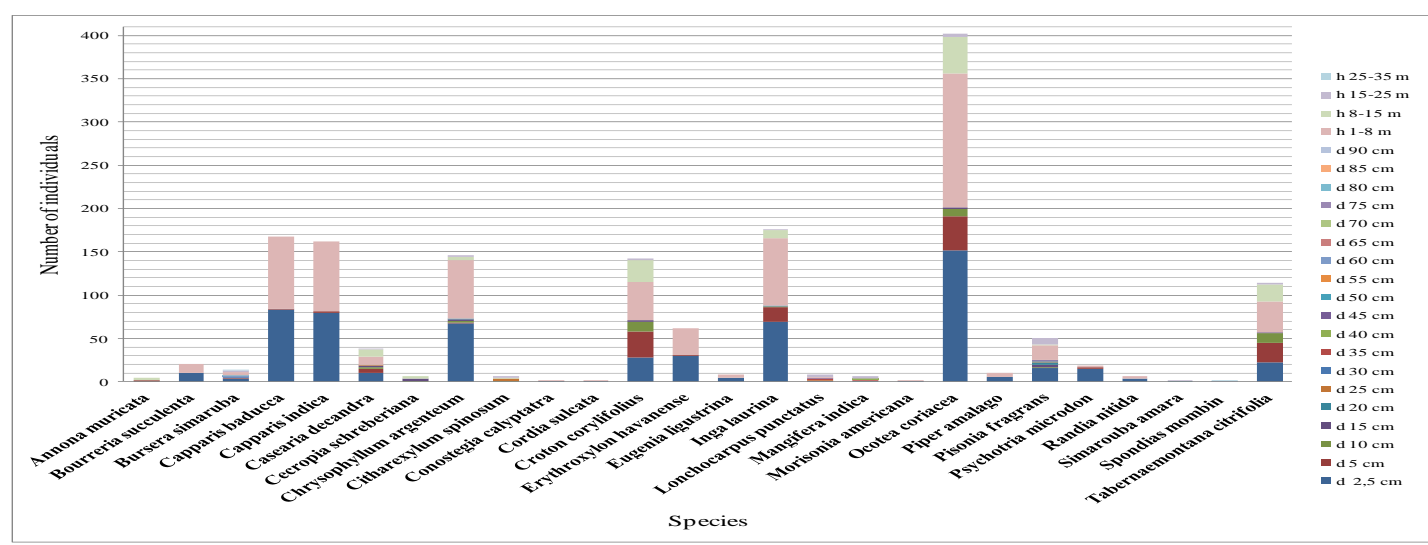

Figure 19: Diameter distribution (d) (diameters $\geq 2.5 \mathrm{~cm}$ ) and heights (h) of live trees (heights $\geq 1 \mathrm{~m}$ ) 
The effects of topography on Martinique's mesological and floristic differentiations: the case of

\subsubsection{Station $17\left(600 \mathrm{~m}^{2}\right.$, Fig. 20)}

Table 17: Key Ecological and Structural Parameters

\begin{tabular}{|l|l|l|l|l|l|l|l|l|}
\hline Species & Family & Af & Rf & $\begin{array}{l}\text { Number of } \\
\text { individuals by } \\
\text { species } \\
\text { excluding } \\
\text { regeneration }\end{array}$ & Density & $\begin{array}{l}\text { Distribution } \\
\text { Index }\end{array}$ & $\begin{array}{l}\text { Total } \\
\text { basal } \\
\text { area } \\
\text { species } \\
\text { by }\end{array}$ & $\begin{array}{l}\text { Index } \\
\text { Dominance }\end{array}$ \\
\hline $\begin{array}{l}\text { Pisonia } \\
\text { fragrans }\end{array}$ & Nyctaginaceae & 6 & $100 \%$ & 118 & 0.11967 & 0.11966667 & 0.40526 & 0.07970040 \\
\hline $\begin{array}{l}\text { Ocotea } \\
\text { coriacea }\end{array}$ & Lauraceae & 6 & $100 \%$ & 72 & 0.12 & 0.12 & 0.11418 & 0.01701487 \\
\hline
\end{tabular}

Absolute frequency (Af): presence of the species in the different quadrats. / Relative frequency $(R f)=$ Absolute frequency / number of quadrats / Density = number of individuals /survey area/ Distribution index = Relative frequency $\times$ Density $/$ Dominance index $=$ Distribution inde $\times$ Land surface $($ basal area $)$.

Pisonia fragrans is a species present in all the quadrats of this survey. It is distributed in a large number of diameter classes and exhibits the highest number of individuals. This translates into an overwhelming ecological dominance. In other words, in this pre-forest tropical seasonal evergreen (mesophilic) floristic group, this taxon is the best adapted to physical or abiotic conditions. The stems with sections between 2.5 and $5 \mathrm{~cm}$ correspond to the individuals in regeneration of the first heights species and to the adults of the lower stratum species forming a dense entity surpassed by Ocotea coriacea, Lonchocarpus punctatus, Bursera simaruba, Citharexylum spinosum, Pisonia fragrans and Zanthoxylum monophyllum adult trees (Fig. 20). Rare species such as Cissampelos pareira and Randia nitida have negligible ecological importance.

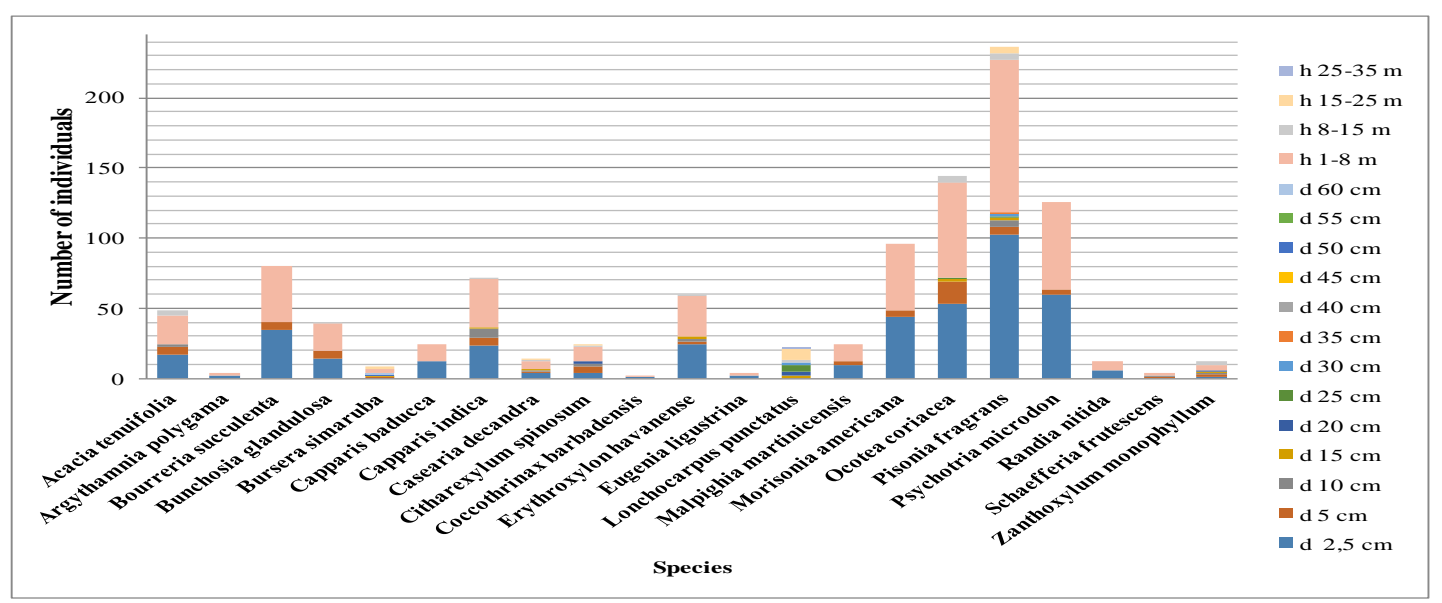

Figure 20: Diameter distribution (d) (diameters $\geq 2.5 \mathrm{~cm}$ ) and heights $(\mathrm{h})$ of live trees (heights $\geq 1 \mathrm{~m}$ )

\subsubsection{Station $18\left(600 \mathrm{~m}^{2}\right.$, Fig. 21)}

Table 18: Key Ecological and Structural Parameters

\begin{tabular}{|l|l|l|l|l|l|l|l|l|}
\hline Species & Family & Af & Rf & $\begin{array}{l}\text { Number of } \\
\text { individuals by } \\
\text { species } \\
\text { excluding } \\
\text { regeneration }\end{array}$ & Density & $\begin{array}{l}\text { Distribution } \\
\text { Index }\end{array}$ & $\begin{array}{l}\text { Total } \\
\text { basal } \\
\text { area by } \\
\text { species }\end{array}$ & $\begin{array}{l}\text { Index of } \\
\text { Dominance }\end{array}$ \\
\hline Pisonia fragrans & Nyctaginaceae & 6 & $100 \%$ & 158 & 0.26333 & 0.26333333 & 0.402 & 0.10749267 \\
\hline $\begin{array}{l}\text { Lonchocarpus } \\
\text { punctatus }\end{array}$ & Fabaceae & 6 & $100 \%$ & 31 & 0.05167 & 0.05166667 & 0.49455 & 0,02555175 \\
\hline
\end{tabular}

Absolute frequency (Af): presence of the species in the different quadrats. / Relative frequency $(R f)=$ Absolute frequency / number of quadrats / Density = number of individuals /survey area/ Distribution index $=$ Relative frequency $\times$ Density $/$ Dominance index $=$ Distribution index $\times$ Land surface $($ basal area) .

This non-structured young forest seasonal evergreen phytocenosis of lower horizon (xerophytic) is also dominated byPisonia fragrans. This results from a balanced ecological profile, a maximal relative frequency with respect to the number of quadrats and a high number of individuals: the diameters and heights range between $2.5 \mathrm{~cm}$ and $5 \mathrm{~cm}$ and between 1 and $25 \mathrm{~m}$ respectively Fig. 21). Compared to the previous station, from the matrix created by the small diameters of adult specimens or those in regeneration emerge mature Pisonia fragrans, Lonchocarpus punctatus, Bourreria succulenta, Citharexylum spinosum, Zanthoxylum caribaeum, Bursera simaruba and Zanthoxylum monophyllum trees. 


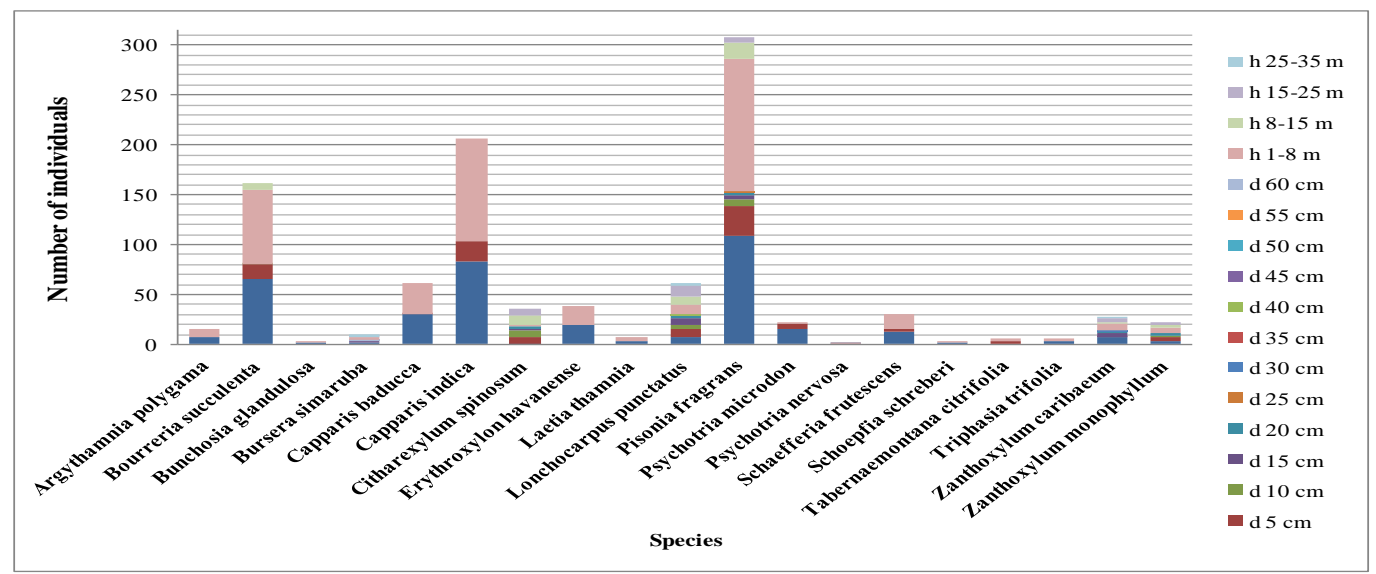

Figure 21: Diameter distribution (d) (diameters $\geq 2.5 \mathrm{~cm}$ ) and heights (h) of live trees (heights $\geq 1 \mathrm{~m}$ )

\subsubsection{Station 19 (700 $\mathrm{m}^{2}$, Fig. 22)}

Table 19: Key Ecological and Structural Parameters

\begin{tabular}{|l|l|l|l|l|l|l|l|l|}
\hline Species & Family & Af & Rf & $\begin{array}{l}\text { Number of } \\
\text { individuals by } \\
\text { species } \\
\text { excluding } \\
\text { regeneration }\end{array}$ & Density & $\begin{array}{l}\text { Distribution } \\
\text { Index }\end{array}$ & $\begin{array}{l}\text { Total } \\
\text { basal } \\
\text { area } \\
\text { species } \\
\text { by }\end{array}$ & $\begin{array}{l}\text { Index } \\
\text { Dominance }\end{array}$ \\
\hline $\begin{array}{l}\text { Bursera } \\
\text { simaruba }\end{array}$ & Burseraceae & 7 & $100 \%$ & 22 & 0.03144 & 0.03142857 & 1.9468 & 0.06118514 \\
\hline $\begin{array}{l}\text { Malpighia } \\
\text { martinicensis }\end{array}$ & Malpighiaceae & 7 & $100 \%$ & 97 & 0,13857 & 0,13857143 & 0.27573 & 0.03820847 \\
\hline
\end{tabular}

Absolute frequency (Af): presence of the species in the different quadrats. / Relative frequency $(R f)=$ Absolute frequency $/$ number of quadrats $/$ Density $=$ number of individuals /survey area/ Distribution index $=$ Relative frequency $\times$ Density $/$ Dominance index $=$ Distribution index $\times$ Land surface $($ basal area $)$.

Due to their relative frequency and their basal area, Bursera simaruba and Malpighia martinicensis form the dominant population within this station. Both species have a balanced bio-demographic profile, indicating a good ability to use the environmental factors. The individuals are represented in several classes of diameters and heights (Fig. 22). The overall architecture of this floristic entity is similar to the previous one: a matrix surmounted by adult trees (Fig. 22). The Randia nitida rare species is poorly distributed and has very low numbers in the form of vulnerable regenerations.

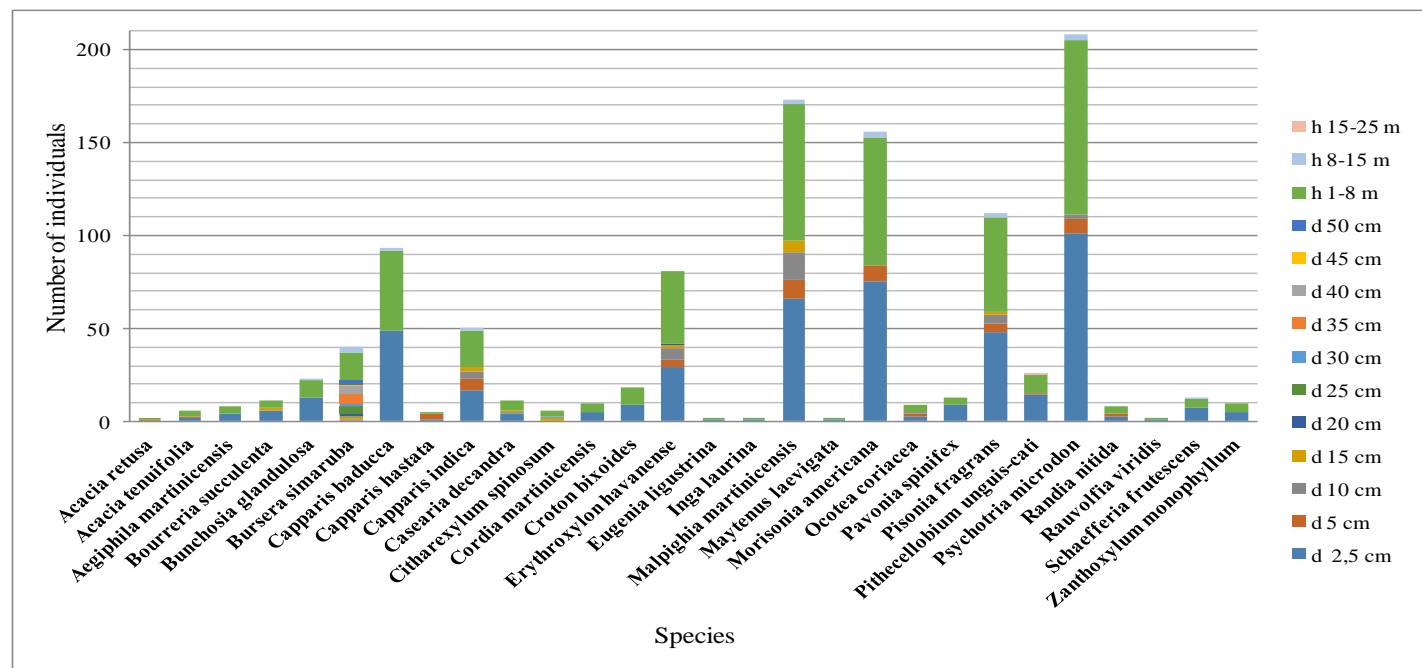

Figure 22: Diameter distribution $(\mathrm{d})$ (diameters $\geq 2.5 \mathrm{~cm}$ ) and heights $(\mathrm{h})$ of live trees (heights $\geq 1 \mathrm{~m}$ ) 
The effects of topography on Martinique's mesological and floristic differentiations: the case of

4.1.20Station $20\left(700 \mathrm{~m}^{2}\right.$, Fig. 23)

Table 20: Key Ecological and Structural Parameters

\begin{tabular}{|l|l|l|l|l|l|l|l|l|}
\hline Species & Family & Af & Rf & $\begin{array}{l}\text { Number of } \\
\text { individuals by } \\
\text { species } \\
\text { excluding } \\
\text { regeneration }\end{array}$ & Density & $\begin{array}{l}\text { Distribution } \\
\text { Index }\end{array}$ & $\begin{array}{l}\text { Total } \\
\text { basal area } \\
\text { by } \\
\text { species }\end{array}$ & $\begin{array}{l}\text { Index } \\
\text { Dominance }\end{array}$ \\
\hline Croton bixoides & Euphorbiaceae & 6 & $100 \%$ & 170 & 0.28333 & 0.28333333 & 0.27769 & 0.07867990 \\
\hline $\begin{array}{l}\text { Guazuma } \\
\text { ulmifolia }\end{array}$ & Sterculiaceae & 6 & $100 \%$ & 70 & 0.11167 & 0.11166667 & 0.32921 & 0.03840776 \\
\hline Cordia sulcata & Boraginaceae & 6 & $100 \%$ & 40 & 0.06667 & 0.06666667 & 0.36257 & 0.02417146 \\
\hline $\begin{array}{l}\text { Citharexylum } \\
\text { spinosum }\end{array}$ & Verbenaceae & 6 & $100 \%$ & 51 & 0.085 & 0.085 & 0.16779 & 0.01426247 \\
\hline
\end{tabular}

Absolute frequency: presence of the species in the different quadrats. / Relative frequency $=$ Absolute frequency $/$ number of quadrats / Density $=$ number of individuals /survey area/ Distribution index $=$ Relative frequency $\times$ Density $/$ Dominance index $=$ Distribution index $\times$ Land surface $($ basal area $)$.

In order of importance the following species, Croton bixoides, Guazuma ulmifolia, Cordia sulcata and Citharexylum spinosum form the dominant floristic population. In general, this pre-forest to young forest formation is composed of a low dense shrub matrix (in principal Croton bixoides) and adult trees or trees in regeneration (between 1 and 8 meters) from which emerge mature subjects of larger diameters (between 10 and $30 \mathrm{~m}$; Fig. 23) and greater heights (between 8 and 35 m; Fig. 23). We mention the presence of Cissampelos pareira, a species considered infrequent. This status must be linked to the complexity of its phenology (its life cycle).

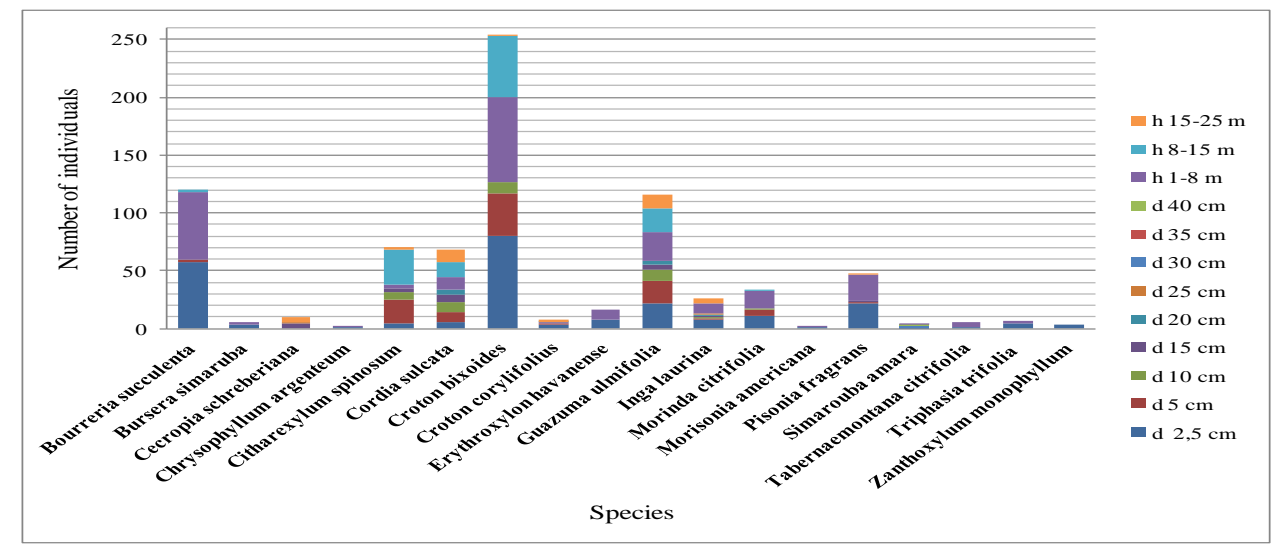

Figure 23: Diameter distribution (d) (diameters $\geq 2.5 \mathrm{~cm}$ ) and heights $(\mathrm{h})$ of live trees (heights $\geq 1 \mathrm{~m})$

\subsection{Overall summary regarding all the stations}

\subsubsection{Floristic dominance}

Pisonia fragrans and Citharexylum spinosum are the most competing species for all the survey stations: this results from the conjunction of a relatively high relative frequency, density and basal area. These two taxa (species) logically constitute the overall preponderant population. Despite their lower Dominance Indices, the following species are nevertheless important from an ecological point of view: Bursera simarubat, Ocotea coriacea, Cordia sulcata, Inga laurina, Simarouba amara, Capparis baducca, Lonchocarpus punctatus, Tabernaemontana citrifolia, Erythroxylon havanense, Capparis indica and Bourreria succulenta. In reality the latter are strongly distributed in the quadrats of the different stations but their smaller numbers are much more concentrated in the smaller diameter classes. This translates into smaller land surfaces (basal areas) with respect to the two dominant species mentioned above. The individuals of the other species are less well distributed in the quadrats of the 20 stations and are often few in number. They are less able to use the environmental factors and their ecological importance is negligible. However, some species are indicators of specific biotopes or dynamic stages. Among the species with very low ecological dominance are those which attempt to start their installation under conditions of ecological secondarization but potentiate their populations throughout the phases of the progressive floristic dynamics: Guazuma ulmifolia, Cupania americana, Randia nitida, Crateva tapia, Coccothrinax barbadensis, Maytenus laevigata, Ocotea cernua and Eugenia tapacumensis. These species are vulnerable because they are not very competitive with regard to mesological factors (environmental or biotope factors). HoweverCupania americana, Randia nitida and Ocotea cernua seem to indicate wetter (more mesophilic) biotopes. 


\subsubsection{Structure, architecture, physiognomy, specific species}

The distribution of the sections by station and for all the surveys shows a concentration of the individuals in the 2.5 and 5 centimeters diameter classes. This is linked to heights between 1 and 8 meters. Except for species with large diameter individuals that create bias in the calculation of the Dominance Index, only those participating in the different dominant station populations have a balanced biodemographic profile (virtually all age groups are represented). Their individuals are classed with variable densities in a large number of diameter classes. From a global and station point of view, the analysis of the distribution profile of the diameters and heights allows us to describe a vegetation consisting of a matrix of low height and small section individuals out of which emerge adult trees of first height (those of the upper stratum) dominated by those of the main floristic population. This floristic matrix consists of adult trees or shrubs of the lower stratum and upper stratum trees in morphological or morphogenetic development. Generally speaking, the recorded physiognomic types correspond to temporal evolution stages ranging from the shrub stage to the young barely structured forest stage by undergoing the intermediate forms, in particular in the pre-forest stage.This elements indicate a regressive or secondary vegetation resulting from the past and present effects of human activities. Most species and the associations they form are common in dry and moderately wet damaged areas of the lower stratum of Martinique's meridional region. They are essentially generalist heliophilous or/and semi-heliophilous species which take part in the first tree succession waves. According to their position on the temporary scale, they can be pioneer or post-pioneer species. In reality, due to the anthropization which in time varied in terms of frequency and intensity, today's vegetation at Morne Carrière is a dense mosaic of floristic units of variable ages, structures and floristic compositions. It is a true heterogenous unit formed by the different stages of evolution specific to damaged areas. The crowns (the canopies) of the survey lot formations are heterogenous and therefore lacunar as they are formed of crowns which are not joined or intertwined.

However, we must mention that we have recorded a few infrequent species such as Cupania americana and Randia nitida: two rather mesophilic species. These are bioclimatic indicators. The first species settles in the young forest stages and potentiates its demography as it progressively evolves to the pre-climax and climax phases (optimal phases of ecosystem evolution). However, in view of its biodemographic structure, where the regenerations and even seedling stage individuals represent the majority, within the vegetal cover of Morne Carrière Cupania americana is highly vulnerable. The seedlings being inversely proportional to the viable regenerations, there is no evidence that the present population is capable of maintaining itself: very high seedling mortality rate. Often we see only one adult, many seedlings and some regenerations. This unbalanced profile poses the problem of this species' durability. The Randia nitida population is represented just by some regenerations and adults. In what regards the Dominance Index, this species has low ecological importance and is therefore not very competitive. Within the same group of specific species we can mention Cissampelos pareira (uncommon creeper), Crateva tapia (uncommon), Coccothrinax barbadensis (post-pioneer to climax phase), Maytenus laevigata (post-pioneer to climax phase), Rivina humilis (uncommon due to its ecology), Ocotea cernua (post-pioneer to climax phase), Eugenia tapacumensis (post-pioneer to climax phase) and Triphasia trifolia (potentially invasive species). These species are of very low ecological importance. So what are the factors that allow taxa specific to mesophilic formations to develop populations within environments influenced by a dry sub-humid bioclimate?

\subsubsection{Species-Survey stations Relationships}

The Factorial Correspondence Analysis (AFC: Axes F1 and F2 concentrate the maximal inertia) carried out using a contingency table made up of the individuals of 110 species (lines) in 20 stations (columns) allowed us to highlight significant differences both from the point of view of the biotopes (environments) associated with the survey stations as well as from the point of view of the stages of evolution and the associated species. Despite the smallness of the study area, the existence of a hill creates two slopes, one exposed to the wind and the other protected from the wind.This geomorphology results in bioclimatic variations in which we can identify xerophytic (dry) and relatively more humid environments that could be described as mesophilic (moderately moist) (Fig. 25).The F1 axis in Figures $24 \& 26$ differentiates between environments with xerophytic tendencies and mesophilic tendencies, whereas the F2 axis differentiates between stages of evolution (stages of plant succession or dynamics: ripe bushes, pre-forests and young barely structured forests). The AFC data are in line with the on-site situation. In Figure 26 the species distribution indicates small to medium differences between the stations although notable for observing differences. 


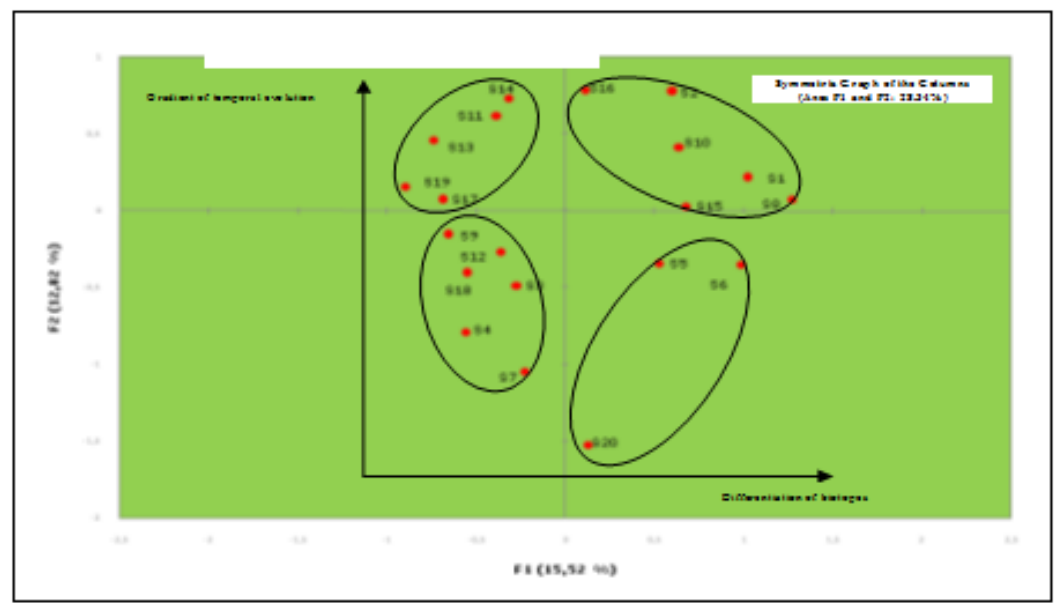

Figure 24: Mesological and Temporal Differentiation of Stations (Appendix 1)

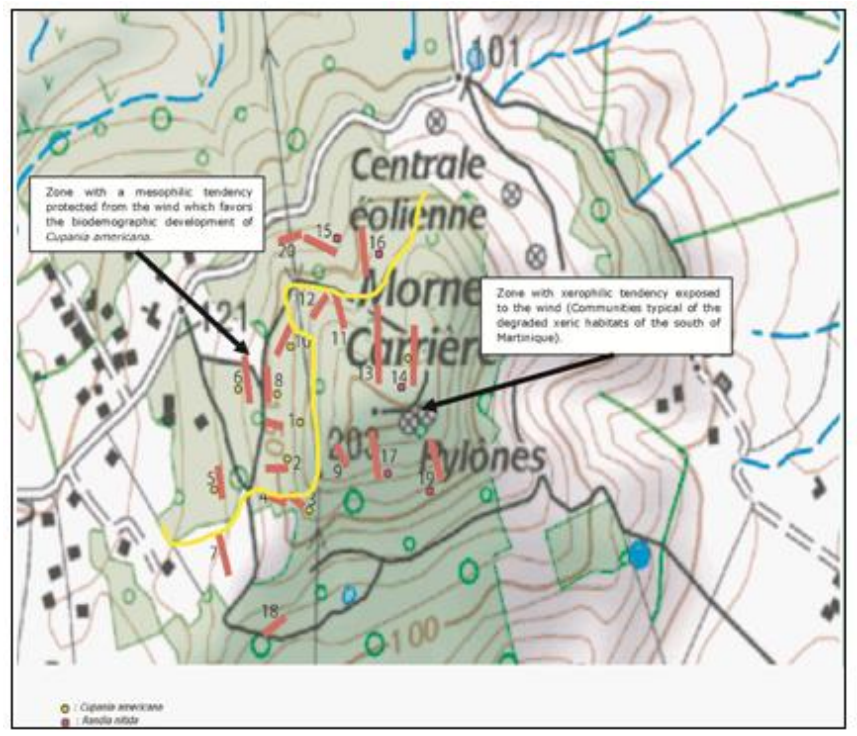

Figure 25: Spatial differentiation of bioclimates

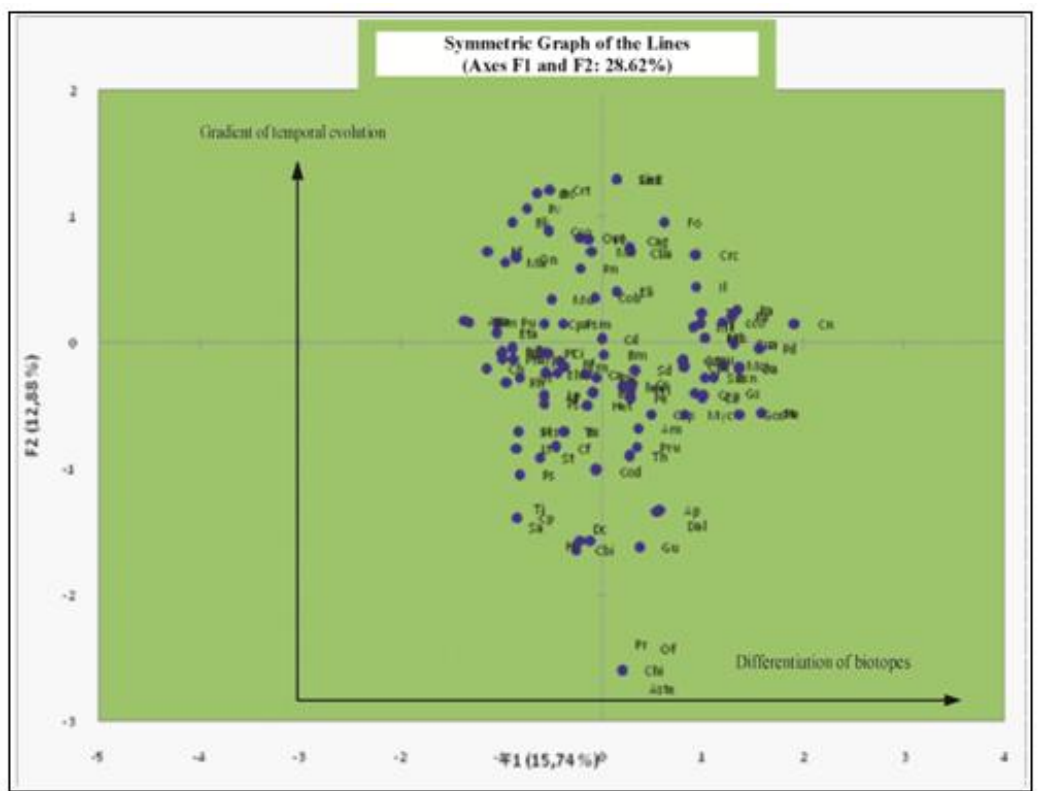

Figure 26: Mesological and temporal differentiation of species (Appendix 1) 


\subsection{Analysis for the characterization of the species at all stations by using a descriptive datamining classification technique: clustering}

The aim is to group the species into a limited number of groups or clusters. These clusters are not predefined by the analyst but emerge after the implementation of the algorithm. Moreover, these clusters group the species with similar characteristics and separate the species with different characteristics (internal homogeneity and external heterogeneity). Unlike component factor analysis, this method has the great advantage of taking into account all the variables without projecting a subspace of smaller dimension. Therefore there is no loss of information. The results below were obtained using the SimpleKmeans and EM (Expectation, Maximization) algorithms.The attributes by species are the following: Name-Species; FreqAbs (Absolute Frequency); FreqRel (Relative Frequency); NberIndEsp (Number of Individuals); Density; Idis (Distribution Index); SurfTerriere (Land Surface); Idomi (Dominance Index).With the basal area (SurfTerriere) on the abscissa and the Distribution Index (Idis) on the ordinate.

\subsubsection{Analysis using the EM software (Expectation, Maximization)}

The blue cluster (cluster 0) identifies the species with a dominance index (Idomi) $>4.2059410^{-4}$ (Idis $>0.001684211$ and SurfTerr $>0.24972814$ ).In Figure 27, we notice a $10^{4}$ coefficient on the abscissa between the species of lesser basal area and the species of larger basal area. On the y-axis, we see a $10^{5}$ coefficient between the species with the lowest and largest index of distribution. The species with a high index of distribution and a large basal area mean that clusters 1 (red) and 2 (green) are little differentiated and are grouped in the vicinity of the origin. Cluster 0 of the balanced species (ecologically more significant) being well identified, we propose to remove these species from the analysis file. Similarly, species with very low values close to 0 for the distribution index as well as for the basal area are also removed from the file, because these species, with very low biomasses, cause the ratios on the abscissa and on the ordinate between the species with the higher and lower values both for the basal area and for the index of distribution to remain important. These are species with a Dominance Index $<1.0743810^{-5}$.

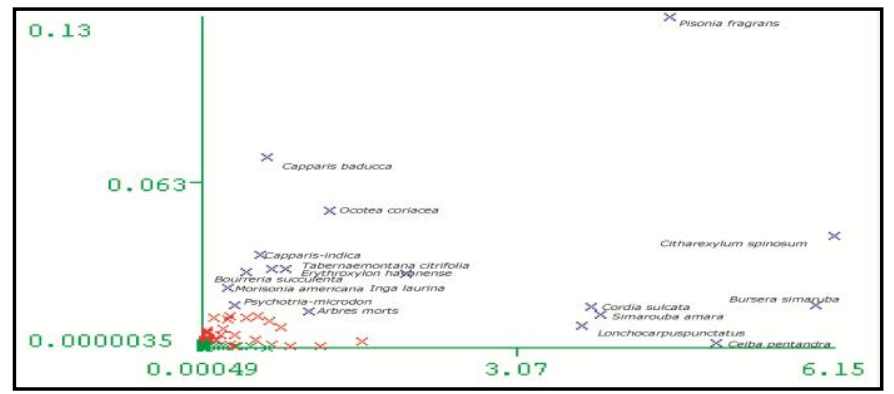

Figure 27: Differentiation of taxa according to their ecological importance

\subsubsection{Processing of the new file data with the SimpleKmeans software ( 2 clusters)}

We notice that the clusters can be differentiated using the distribution index (Idis) and not at all using the basal area. Cluster 1 (blue) represents the best distributed species with low to medium Ground Surface (Idis $>0.00483$ and SurfT $>0.055440625$ ). One exception is the Ceiba-pentandra.Cluster 2 (red) which shows the weakly distributed species with basically low and medium basal areas for a few units (Fig. 28). In the figure below we essentially obtain the same type of clustering by using the same set of data and the EM (Expectation Minimization) algorithm. With regard to the exception concerning the Ceiba pentandra species, this time this species is found in the red cluster (Fig. 29).

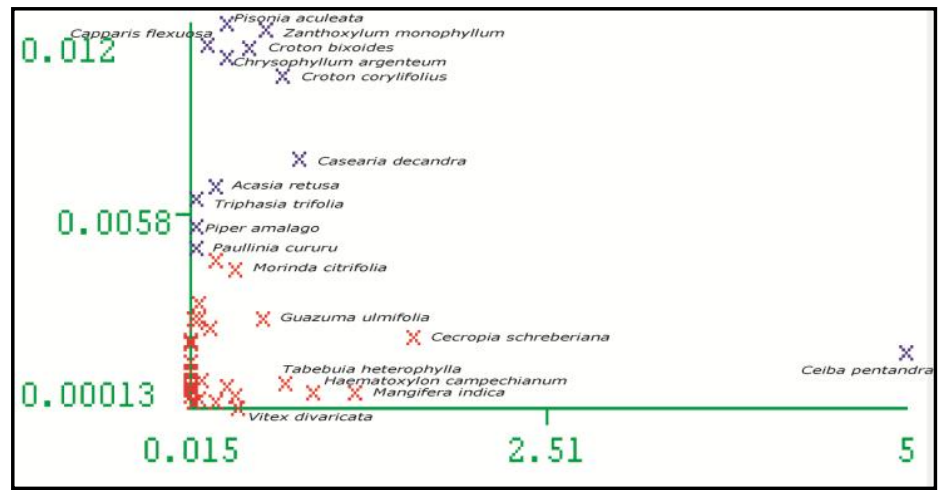

Figure 28: Autoecological Differentiation of Taxa 


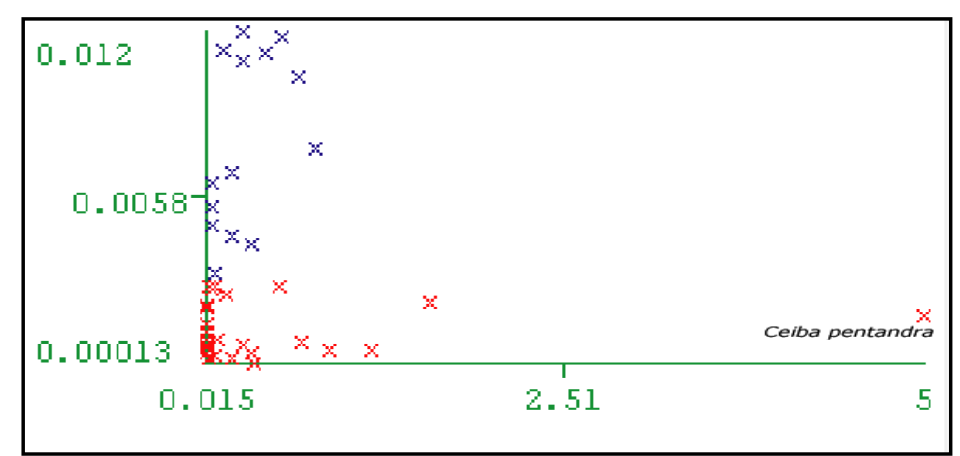

Figure 29: Autoecological Differentiation of Taxa

\section{Discussion And Conclusion}

Within the very secondary vegetation of Morne Carrière (Fig. 2), we recorded species infrequent on the scale of Martinique such that Cupania americana, Cissampelos will pareira, Crateva tapia,Rivina humilis, Randia nitida and Eugeniatapacumensis. Apart from the seedlings which are by nature fragile, these (these infrequent species) are either erratic or have very low ecologically vulnerable populations, often consisting of one or two adults and a small number of regenerations. Triphasia trifolia and Laetia thamnia) are two species in progression from the point of view of their population and two future pest species of the regressive formations of Martinique's dry bioclimate zones.Despite the existence of a Cupania americana and Randia nitida population, the Morne Carrière vegetation is very regressive. The recorded species are common to all the secondary formations of the island's southern region. The latter are shrubby, pre-forest and young forest formations and are often formed by a matrix of small stems surmounted by adult trees whose heights range, on average, between 8 and 20 meters. The on-site situation results in non-intertwined canopies called lacunar. According to their degree of openness, these canopies with non-joining crowns also represent indicators of ecosystem states: young phases of the intra-forest succession concerning the study of the Morne Carrière vegetation.

The floristic units colonizing the various topographic facies result, in part, from an anthropization variable in frequency and intensity. They form a dense mosaic of evolution stages, structures and floristic compositions as numerous as they are varied. The middle and lower thirds of the western slope influenced by the dry sub-humid bioclimate seem to allow the establishment of affine species of the mesophilic formations that normally develop within the wet sub-humid bioclimatic floor (Fig. 25). The most representative species are: Cupania americana, Randia nitida, Cordia sulcata, Inga laurina, Simarouba amara, Tabernaemontana citrifolia, Ceiba pentandra, Cecropia schreberiana, Chrysophyllum argenteum, Guazuma ulmifolia, Morinda citrifolia, Piper amalago,Odontonema nitidum, Bunchosia glandulosa, Piper dilatatum, Aegiphila martinicensis, Conostegia calyptatra, Zanthoxylum caribaeum, Vitex divaricata, Macfadenya unguis cati, Gonzalagunia spicata, Justicia secunda, Samanean saman, Trichostigma octandrum, Spondias mombin, Dioscorea alata, Solanum torvum, Securidaca diversifolia, Heliconia sp, Peperomia myrtifolia, Passiflora suberosa, Passiflora laurifolia, Inga ingoides et Ocotea cernua. The latter participate in various phytocenoses composed mainly of taxa typical of the dry sub-humid bioclimate. Within these formations whose xeric character is linked to the regression or secondarization stage, the above mentioned taxa of mesophilic affinity occupy a marginal position from a population or biodemographic point of view.

The above mentioned elements show that by creating a barrier, with a slope exposed to the wind and a leeward slope, over a very short distance the topography significantly modifies certain climatic factors such as humidity and evapotranspiration (Fig. 24, 25 \& 26). In this case, the relatively greater intra-vegetation water resource of the Morne Carrière protected slope (Fig. 2) gives it a more mesophilic character. This allows the installation, in small populations, of species belonging to the formations of the middle plant floor called mesophilic or evergreen tropical seasonal types corresponding to the wet sub-humid bioclimate. Nevertheless, throughout an evolution without anthropogenic constraints, these species will gradually see their population densities increase (all age groups) as well as the associated biomasses. The topography, climate and human activities are constantly contributing to the maintenance of a dense floristic mosaic. The population relationships between species and therefore their ecological importance have been highlighted due to the use of the SimpleKmeans and Expectation-Maximization (EM) algorithms. The obtained results also seem to indicate some autoecological characteristics of the species and therefore provide information on their ecological profiles. The presence of mesophilic species within the vegetation of the Morne Carrière wind protected slope (Fig. 2) created by a dry sub-humid macroclimate is an ecosystemic response demonstrating topologically induced mesological variations. This differentiation phenomenon is even more marked on the higher mountains of the Lesser Antilles and leads to the installation of vegetation belts along the increasing altitude. In reality, due to the 
The effects of topography on Martinique's mesological and floristic differentiations: the case of

variety of its facies the topography results in a plurality of biotopes which host species of various ecological profiles. In general, the ridges, the upwind and downwind slopes, the valleys and gullies of multiple and varied dimensions are all promoters of floristic biodiversity.

Appendix 1: Key Ecological and Structural Parameters

\begin{tabular}{|c|c|c|c|c|c|c|c|c|}
\hline Syosier & Fanly & $A f$ & $2 f$ & 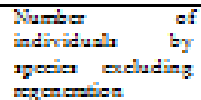 & Denxisy & $\begin{array}{l}\text { Diatebutien } \\
\text { hdex }\end{array}$ & $\begin{array}{l}\text { Tetal baal atea } \\
\text { by rocede }\end{array}$ & $\begin{array}{l}\text { hdex ef } \\
\text { Deminsese }\end{array}$ \\
\hline Drexis fragraxs & Syetaginaces: & 20 & $100 \%$ & 1732 & 0.12505263 & 0.12505263 & 4.56870001 & 0.571327959 \\
\hline 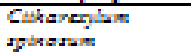 & Vécensecte & 20 & $100 \%$ & 506 & 0.04132456 & 0.04132456 & 6,14302133 & 0.257138310 \\
\hline Burrera sinaraba & Buneraese & 20 & $100 \%$ & 221 & 0.01550377 & 0.01550377 & 5976303135 & 0.002635122 \\
\hline Qsoles egriasens & Lameese & 20 & $100 \%$ & 732 & 0.05136342 & 0.05136342 & 1.252565635 & 0.064342318 \\
\hline Condia nilasia & Beraginactaz & 13 & $65 \%$ & 335 & 0.02350377 & 0.01528070 & $3,790073: 3$ & 0.057915054 \\
\hline Laga lasorisa & Simeraesen & 15 & $75 \%$ & 525 & 0.03634211 & 0.02763158 & 1,90739493 & 0.055139503 \\
\hline Simarobatamara & Simpreukacese & 13 & $65 \%$ & 262 & 0.01839506 & 0.01105038 & 3.33373751 & 0.046414663 \\
\hline Cagparis badivesa & Csypenesas & 18 & $90 \%$ & 1134 & 0.07957805 & 0.07162105 & 0.63736126 & 0.045643434 \\
\hline $\begin{array}{l}\text { Iandasesyous } \\
\text { gareistas }\end{array}$ & Fakacese & 16 & sow & 140 & 0.00032456 & 0.00735065 & 3,604306335 & 0.020040503 \\
\hline 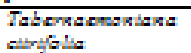 & Aресупасы: & 13 & $90 \%$ & 460 & 0.03201223 & 0.02962105 & 0.82015627 & 0.024560432 \\
\hline $\begin{array}{l}\text { Eydkraxion } \\
\text { kavaroxse }\end{array}$ & Eythrexylaesese & 20 & $100 \%$ & 422 & 0.02061404 & 0.02961403 & 0.679025005 & 0.02010367 \\
\hline Cagparis bxdisas & Cryomesas & 10 & $95 \%$ & 522 & 0.03663153 & 0.0343 & 0.567653125 & 0.018754320 \\
\hline Desd bert & & 17 & asw & 220 & 0.0154336 & $0.013: 2231$ & 1.058278135 & 0.01393758 \\
\hline $\begin{array}{l}\text { Basmoria } \\
\text { nesclesia }\end{array}$ & Benginaces: & 18 & $90 \%$ & 444 & 0.03115730 & 0.02804210 & 0.42073751 & 0.012052147 \\
\hline Celba poriandina & Bemingeneras & 10 & $50 \%$ & 43 & 0.00396342 & 0.00163421 & 5,0024125 & 0.003425116 \\
\hline 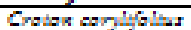 & Euphethiaesas & 9 & $45 \%$ & 316 & 0.02217544 & 0.00007305 & 0.673137505 & 0.006717204 \\
\hline 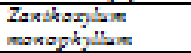 & Rutacese & 17 & $85 \%$ & 190 & 0.013339333 & 0.01133393 & 0.552934375 & 0.00626650 \\
\hline Canesura dosandina & Flaseutiacens & 17 & $85 \%$ & 126 & 0.00334211 & 0.00751579 & 0.787043755 & 0.005022010 \\
\hline $\begin{array}{l}\text { Drokebia } \\
\text { milordan }\end{array}$ & Rulaiacese & 17 & $35 \%$ & 371 & 0.02603500 & 0.02212932 & 0.24072314 & 0.00552644 \\
\hline $\begin{array}{l}\text { Worisenis } \\
\text { amolesas }\end{array}$ & Csponeste & 10 & $50 \%$ & 454 & 0.03135065 & 0.01502932 & 0.3103375 & 0.005005752 \\
\hline Crolon blagider & Euphethiaeser & 10 & $50 \%$ & 303 & 0.02161404 & 0.01030702 & 0.430763755 & 0.004655325 \\
\hline $\begin{array}{l}\text { Cosorgia } \\
\text { neknabolase }\end{array}$ & 3Seraeses & it & $55 \%$ & 57 & 0.004 & 0.0022 & 1.575306375 & 0.003465373 \\
\hline Drania aclosta & Syctagingecte & 18 & $90 \%$ & 183 & 0.01284211 & 0.01155798 & 0.27524063 & $0.00318: 202$ \\
\hline $\begin{array}{l}\text { Chravgkyllon } \\
\text { argorienm }\end{array}$ & Sogetaces: & 15 & $75 \%$ & 100 & 0.01396401 & 0.01047368 & 0.263362505 & $0.00281503:$ \\
\hline Cussums ainetolus & Stercen liacens: & 7 & $35 \%$ & 113 & 0.00792032 & 0.00277544 & 0.52340630 & 0.001452933 \\
\hline Cagparis ferasa & Crypanase & 16 & $80 \%$ & 193 & 0,01354336 & 0.01033500 & 0.1314375 & 0.001424679 \\
\hline Marsada elofolla & Rukiacese & 9 & $45 \%$ & 133 & 0.00039333 & 0.0042 & 0.390190645 & 0.001386301 \\
\hline Lesela netsa & Simeraesas & 17 & $35 \%$ & t:t & 0.00773047 & 0.00662105 & 0.20704375 & 0.001370343 \\
\hline $\begin{array}{l}\text { Cagania } \\
\text { amoreana }\end{array}$ & Ssyindacese & it & $55 \%$ & $1: 7$ & 0.00321053 & 0.00451570 & 0.10063437 & 0.000001733 \\
\hline Kaxg fora badisa & Anacediaceas & 5 & $25 \%$ & 33 & 0.00231579 & 0.00057905 & 1,1637625 & 0.000673757 \\
\hline $\begin{array}{l}\text { Tababois } \\
\text { keorogkylla }\end{array}$ & Bigneniaeces & 6 & $\operatorname{tin} \alpha$ & 37 & 0.00250640 & 0.000773047 & 0.63735625 & 0.000535304 \\
\hline 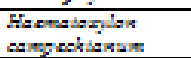 & Cerabiniases: & 2 & $10 \%$ & 78 & 0.00547363 & 0.000547963 & 0.877723125 & 0.000430441 \\
\hline Lestela texpitolus & Simeraetes: & 8 & $40 \%$ & 39 & 0.00624561 & 0.00240325 & 0.150621875 & 0.00037620 \\
\hline Dog amalage & Figeneens & 12 & $60 \%$ & 131 & 0.00019203 & 0.00551530 & 0.064271875 & 0.00035451 \\
\hline Trigkasia b b & Rutaceas & 16 & sow & 113 & 0.00792932 & 0.00634396 & 0.055440625 & 0.000351703 \\
\hline 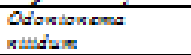 & Aesthaceas & 5 & $25 \%$ & ist & 0.01270175 & 0.00317544 & 0.033303125 & 0.000231030 \\
\hline Datlinis aras & Sogindaces: & 20 & $100 \%$ & 60 & 0.00434211 & 0.00434210 & 0.05593125 & 0.000270325 \\
\hline $\begin{array}{l}\text { Majoigkia } \\
\text { marosisorsis }\end{array}$ & 3labighiaces & 2 & $10 \%$ & 100 & 0.00764012 & 0.00076401 & 0.236034375 & 0.000218791 \\
\hline $\begin{array}{l}\text { Sarekeria } \\
\text { glandulara }\end{array}$ & Malgighiaese & 7 & $35 \%$ & 113 & 0.00792032 & 0.002775439 & 0.07604683 & 0.000211063 \\
\hline Clbieldis segtam & Fatseces: & 5 & $25 \%$ & 28 & 0.00196401 & 0.00040123 & 0.3962525 & 0.000163836 \\
\hline Dgo dilatatam & Digeraetes & 6 & thish & 125 & 0.00377193 & 0.00263158 & 0.061323125 & 0.00016139 \\
\hline 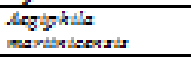 & Vétensesa: & 10 & $50 \%$ & 70 & 0.00554336 & 0.00277193 & 0.040231255 & $0.0001: 1513$ \\
\hline Lanena mariedia & Annengesas & 10 & $50 \%$ & 26 & 0.00132456 & 0.00001228 & 0.10597501 & $9,6670 \mathrm{E}-05$ \\
\hline
\end{tabular}


The effects of topography on Martinique's mesological and floristic differentiations: the case of

\begin{tabular}{|c|c|c|c|c|c|c|c|c|}
\hline $\begin{array}{l}\text { Conoriegia } \\
\text { extygiatax }\end{array}$ & SSelatasmenaceser & 9 & $45 \%$ & 66 & 0.00463153 & 0.00203421 & 0.033353125 & $7,0557 \mathrm{E}-05$ \\
\hline $\begin{array}{l}\text { Zaxkanim } \\
\text { aspibanim }\end{array}$ & Rutactas & 4 & $20 \%$ & 20 & 0.00140351 & 0.00023070 & 0.20503125 & $5,75667 \mathrm{E}-05$ \\
\hline Chisososes alba & Rubiactas & 12 & $60 \%$ & 43 & 0.00396342 & 0.00202105 & 0.02355 & $4,75059 \mathrm{E}-05$ \\
\hline Ther dinarilesian & Vexensests & 4 & $20 \%$ & 9 & 0.00063153 & $0.000: 2632$ & 0.3552125 & $4,436 \mathrm{Bg}=05$ \\
\hline $\begin{array}{l}\text { Sekacforis } \\
\text { fostereots }\end{array}$ & Celatanescas & 12 & $55 \%$ & 38 & 0.00266667 & 0.00146667 & 0.03041875 & $4,46142 \mathrm{E}-05$ \\
\hline $\begin{array}{l}\text { Argikamala } \\
\text { galigans }\end{array}$ & Eughertiacese & 7 & $35 \%$ & 49 & 0.0034336 & 0.00120351 & 0.024040625 & 2.3933:E-05 \\
\hline daxdisa anicala & Rubiasese & 8 & $40 \%$ & 41 & 0.00287718 & 0.00115030 & 0,02453125 & $2.82325 \mathrm{E}-05$ \\
\hline 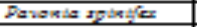 & 3tahraetas & $\mathrm{s}$ & $40 \%$ & 43 & 0.00301754 & 0.00120701 & 0.021006375 & $2.54643 \mathrm{E}-0.5$ \\
\hline Cordis es Horesess & Berpyinaceses & 5 & $25 \%$ & 19 & 0.001 .99393 & 0.00033393 & 0.07310913 & $2,43677 \mathrm{E}-05$ \\
\hline 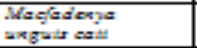 & Bigneniacene & 11 & $55 \%$ & 24 & 0.00169421 & 0.00002632 & 0.022079125 & $2.04513 \mathrm{E}-05$ \\
\hline 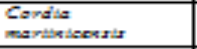 & Baraginacese & 7 & $35 \%$ & 24 & 0.00168421 & 0.00059047 & 0.030000375 & 1.82203E-05 \\
\hline Drokabla nonass & Rubiacesas & 11 & $55 \%$ & thisy & 0.00210526 & 0.00115790 & 0.01471975 & $1,7042 \mathrm{gE}-05$ \\
\hline $\begin{array}{l}\text { Conzalogexis } \\
\text { splestax }\end{array}$ & Rubiacese & 5 & $25 \%$ & 41 & 0.00237710 & 0.00071930 & 0.020115625 & $1.44601 \mathrm{E}-05$ \\
\hline 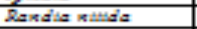 & Rubiacese & 5 & $25 \%$ & 36 & 0.00252632 & 0.00063160 & 0.0220731 .25 & $1.39441 \mathrm{E}-05$ \\
\hline 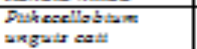 & Simeracese & 7 & $35 \%$ & 18 & 0.00139393 & 0.00046667 & 0.027065625 & $1.30506 \mathrm{E}-05$ \\
\hline 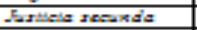 & Alemthoestas & 1 & $5 \%$ & 79 & 0.00554336 & 0.00027718 & 0.038759375 & $1.07493 \mathrm{aE}-05$ \\
\hline $\begin{array}{l}\text { Casabigstat } \\
\text { bordue }\end{array}$ & Cacualyiniaeste & $\mathrm{s}$ & $40 \%$ & 20 & 0.00140351 & 0.00056140 & $0.014223: 25$ & $7,93772 \mathrm{E}-06$ \\
\hline $\begin{array}{l}\text { Cirrangelor with } \\
\text { gareina }\end{array}$ & Seniagentecen & 6 & $\sin 2 \%$ & 26 & 0.00192456 & 0.00054737 & 0.01275625 & $6,93237 \mathrm{E}-06$ \\
\hline Samaneas asman & SSimeraesan & $t$ & $5 \%$ & 3 & 0.00021053 & $1.05263 \mathrm{E}-05$ & 0.432775 & $5.03134 \mathrm{E}-06$ \\
\hline 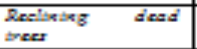 & & $\frac{2}{2}$ & 100 & 4 & 0.0002807 & $2,80702 \mathrm{E}-05$ & 0.166312 .5 & $4,63246 \mathrm{E}-06$ \\
\hline 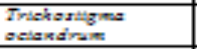 & Daytelaecaedas & 5 & $25 \%$ & 20 & 0.00140351 & 0.000350377 & 0.0003125 & $3,44293 \equiv-06$ \\
\hline Sgandisa manbst & Ansecendiaces: & $\frac{1}{2}$ & $5 \%$ & 1 & $7,0175 E-05$ & $3,50377 \mathrm{E}-06$ & 0.63595 & $2,23105 \mathrm{E}-06$ \\
\hline 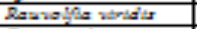 & Agachanactas & 3 & $15 \%$ & 16 & 0,00112281 & 0.000169421 & 0.00735 & $1.32211 \mathrm{E}-06$ \\
\hline 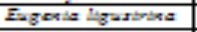 & $3 \mathrm{Sy}$ theeras & 12 & $60 \%$ & $\mathrm{~s}$ & 0.0005614 & 0.000336342 & 0.003925 & $1.32211 \mathrm{E}-06$ \\
\hline $\begin{array}{l}\text { Diekrosiackys } \\
\text { exteres }\end{array}$ & $3 \operatorname{simeracese}$ & 2 & 100 & 9 & 0.00063153 & $6,31570 \mathrm{E}-05$ & 0.02060625 & $1,30145 \mathrm{E}-06$ \\
\hline 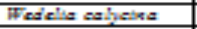 & Axtemestas & 2 & $20 \%$ & 16 & 0,00112281 & $0.0001: 2231$ & 0.00785 & $3,3: 404 \mathrm{E}-07$ \\
\hline Craina sagia & $\mathrm{Cryp}_{\mathrm{n}}$ & $\frac{1}{2}$ & $5 \%$ & 2 & 0.00014035 & $7,01754 \mathrm{E}-06$ & 0.1193925 & $7,93772 \mathrm{E}-07$ \\
\hline Diaregres alosia & Diencemenestas & 5 & $25 \%$ & 8 & 0.00063153 & 0.000157995 & 0.00441 .562 .5 & $6.97204 \mathrm{E}-97$ \\
\hline Sudx assa? & 3tahraesas & $i$ & sM & 13 & 0.00126316 & $6,31579 \mathrm{E}-05$ & 0.0033312 .5 & $5,57763 \mathrm{E}-07$ \\
\hline Endlles aimases & Sogindacest & 15 & $75 \%$ & 4 & 0.0002307 & 0.000210526 & 0.001962 .5 & $4,1315 \mathrm{AE}-07$ \\
\hline Salaxam Agrain: & Salunaceas & 4 & $20 \%$ & 7 & 0.00049123 & $9.92456 \mathrm{E}-05$ & 0.003434375 & $3,37412 \mathrm{E}-07$ \\
\hline Cagparis haxiala & $\mathrm{Crgy}_{\mathrm{Sg}}$ & 2 & $10 \%$ & 5 & 0.00035033 & $3,50377 \mathrm{E}-05$ & 0.00636375 & $2,41000 \mathrm{E}-07$ \\
\hline Crensertis ajeif & Bispentiacens & $i$ & $5 \%$ & $i$ & $7,0175 \mathrm{E}-05$ & $3,50377 \mathrm{E}-06$ & 0.040062 .5 & $1.72140 \mathrm{E}-07$ \\
\hline Tamariadiox tadisas & Fahaesas & 1 & 5M & 1 & $7,0175 E-05$ & $3,50377 \mathrm{E}-06$ & 0.0314 & $1,201755-07$ \\
\hline $\begin{array}{l}\text { Heieragters } \\
\text { porpares }\end{array}$ & 3halgighiaeser & 13 & $65 \%$ & 2 & 0.00014035 & $9,1228: 5-05$ & 0.00003125 & 3,95175E-03 \\
\hline Lacelas thamoras & Flaceutiacens & 2 & $10 \%$ & 5 & 0.00035033 & $3,50377 \mathrm{E}-05$ & 0.00245312 .5 & $3.60746 \mathrm{E}-0 \mathrm{~g}$ \\
\hline Isanex & & 2 & $10 \%$ & 2 & 0.00014035 & $1.40351 \mathrm{E}-05$ & 0.00392 .5 & $5,50377 \mathrm{E}-0 \mathrm{~A}$ \\
\hline Lbras gressigras & Fahaecas & 5 & $25 \%$ & 2 & 0.00014035 & $3,50377 \mathrm{E}-05$ & 0.0000312 .5 & $3,44293 \mathrm{E}-0 \mathrm{a}$ \\
\hline Isasel & & $i$ & $5 \mathrm{~W}$ & $i$ & $7,0175 \mathrm{E}-05$ & $3,50377 \mathrm{E}-06$ & 0.00735 & $2,75439 \mathrm{E}-0 \mathrm{~A}$ \\
\hline 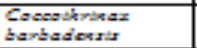 & Ambederas & 10 & $50 \%$ & 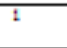 & $7,0175 \mathrm{E}-05$ & $3,50377 \mathrm{E}-05$ & 0.000400625 & $1.72140 \mathrm{E}-0 \mathrm{~B}$ \\
\hline Catboer & & $t$ & $5 \mathrm{~W}$ & 3 & 0.00021053 & $1.05263 \mathrm{E}-05$ & 0.001471875 & $1.54934 \mathrm{E}-0 \mathrm{3}$ \\
\hline 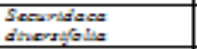 & Dabyzalaeese & 8 & $45 \%$ & 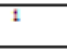 & $7,0175 \mathrm{E}-05$ & $3,1.5730 \mathrm{E}-0.5$ & 0.00040062 .5 & $1.54034 \mathrm{E}-0 \mathrm{3}$ \\
\hline $\begin{array}{l}\text { Sokaghis } \\
\text { seknchert }\end{array}$ & Olacueste & $t^{2}$ & $5 \%$ & 2 & 0.00014035 & $7,01754 \mathrm{E}-06$ & 0.00003125 & $6,33506 \mathrm{E}-00$ \\
\hline Isane 2 & & $t$ & $5 \%$ & $i$ & $7,0175 \mathrm{E}-05$ & $3,50377 \mathrm{E}-06$ & 0.001062 .5 & $6.39506 \mathrm{E}-00$ \\
\hline $\begin{array}{l}\text { Mayderax } \\
\text { Lanigasa }\end{array}$ & Celarmesta: & 3 & $15 \%$ & $t^{2}$ & $7,0175 E-05$ & $1.05263 \mathrm{E}-05$ & 0.00040062 .5 & $5.16447 \mathrm{E}-00$ \\
\hline Risus kamity & Physellacederas & 2 & $10 \%$ & $\frac{1}{1}$ & $7,0175 \mathrm{E}-05$ & $7,01754 \mathrm{E}-06$ & 0.000400625 & $3,44203 \mathrm{E}-00$ \\
\hline Erwkats fraellegra & Rubiaseas & 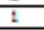 & 5\% & $i$ & $7,0275 E-05$ & $3,50377 \mathrm{E}-06$ & 0.00049062 .5 & $1.72140 \mathrm{E}-00$ \\
\hline Qegies aensa & Lumestas & $\frac{1}{1}$ & $5 \%$ & $i$ & $7,0175 \mathrm{E}-05$ & $3,50377 \mathrm{E}-06$ & 0.00040062 .5 & $1.72140 \mathrm{E}-00$ \\
\hline . Mateseses & Ssyindacese & $\mathrm{i}$ & $5 \%$ & $t^{2}$ & $7,01755-05$ & $3,50377 \mathrm{E}-06$ & 0.000400625 & $1.72140 \mathrm{E}-00$ \\
\hline \multicolumn{9}{|l|}{ bijugatus } \\
\hline Heliconia $s p$ & Heliconiaceae & 1 & $5 \%$ & 1 & $7,0175 \mathrm{E}-05$ & $3,50877 \mathrm{E}-06$ & 0.000490625 & $1.72149 \mathrm{E}-09$ \\
\hline Carica papava & Caricaceae & 1 & $5 \%$ & 1 & $7,0175 \mathrm{E}-05$ & $3,50877 \mathrm{E}-06$ & 0.000490625 & $1.72149 \mathrm{E}-09$ \\
\hline Tree deciduous & & 1 & $5 \%$ & 1 & $7,0175 \mathrm{E}-05$ & $3,50877 \mathrm{E}-06$ & 0.000490625 & $1.72149 \mathrm{E}-09$ \\
\hline Tragia volubilitis & Euphorbiacase & 11 & $55 \%$ & & & & & \\
\hline Priva lappulacea & Verbenaceae & 4 & $20 \%$ & & & & & \\
\hline Pimenta racemosa & Myrtaceae & 1 & $5 \%$ & & & & & \\
\hline $\begin{array}{l}\text { Phoradendron } \\
\text { trinervium }\end{array}$ & Viscaceale & 6 & thirty $\%$ & & & & & \\
\hline Pharus latifolius & Poaceae & 4 & $20 \%$ & & & & & \\
\hline $\begin{array}{l}\text { Peperomia } \\
\text { myrtifolia }\end{array}$ & Piperaceae & 4 & $20 \%$ & & & & & \\
\hline $\begin{array}{l}\text { Passifiora } \\
\text { suberosa }\end{array}$ & Passifloracease & 12 & $60 \%$ & & & & & \\
\hline Passifiora rubra? & Passifloracease & 2 & $10 \%$ & & & & & \\
\hline $\begin{array}{l}\text { Passifiora } \\
\text { laurifolia }\end{array}$ & Passifloraceae & 1 & $5 \%$ & & & & & \\
\hline Passifiora edulis & Passifloraceae & 2 & $10 \%$ & & & & & \\
\hline Oxalis frutescens & Oxalidacease & 1 & $5 \%$ & & & & & \\
\hline Murcia citrifolia & Myrtaceae & 1 & $5 \%$ & & & & & \\
\hline $\begin{array}{l}\text { Momordica } \\
\text { charantia }\end{array}$ & Curcurbitaceae & 1 & $5 \%$ & & & & & \\
\hline Inga ingoides & Mimosacese & 1 & $5 \%$ & & & & & \\
\hline Herbaceous & Poacease & 3 & $15 \%$ & & & & & \\
\hline Fougeres & & 3 & $15 \%$ & & & & & \\
\hline $\begin{array}{l}\text { Ficus citrifolia } \\
\text { uprooted }\end{array}$ & Moracease & 1 & $5 \%$ & & & & & \\
\hline $\begin{array}{l}\text { Eugenia } \\
\text { tapacumensis }\end{array}$ & Myrtacese & 1 & $5 \%$ & & & & & \\
\hline $\begin{array}{l}\text { Daphnopsis } \\
\text { americana }\end{array}$ & Thymeleaceae & 2 & $10 \%$ & & & & & \\
\hline Compound & Asteraceae & 1 & $5 \%$ & & & & & \\
\hline Commelina diffusa & Commelinaceae & 3 & $15 \%$ & & & & & \\
\hline Cocos nucifera & Arecaceale & 1 & $5 \%$ & & & & & \\
\hline Clidemia hirta & Melastomataceae & 1 & $5 \%$ & & & & & \\
\hline Bromelia karatas & Bromeliaceae & 1 & $5 \%$ & & & & & \\
\hline Bambusa multiplex & Poaceas & 20 & $100 \%$ & & & & & \\
\hline $\begin{array}{l}\text { Altemating } \\
\text { paronvehoides? }\end{array}$ & Amaranthaceae & 1 & $5 \%$ & & & & & \\
\hline
\end{tabular}


Absolute frequency $(A f)$ : presence of the species in the different quadrats. / Relative frequency $(R f)=$ Absolute frequency / number of quadrats / Density = number of individuals / area of survey / Distribution index = Relative frequency $\times$ Density $/$ Dominance index $=$ Distribution index $\times$ land surface $($ Basal area $)$.

\section{References}

[1]. P. Bouysse, The Lesser Antilles Island-Arc-Structure and geodynamic evolution, Initial Reports of the Deep Sea Drilling Project, 78(AUG), 1984, 83-103.

[2]. A. Germa,X. Quidelleur,S. Labanieh, P. Lahitte, and C. Chauvel, The eruptive history of Morne Jacob volcano (Martinique Island, French West Indies): Geochronology, geomorphology and geochemistry of the earliest volcanism in the recent Lesser Antilles arc, Journal of Volcanology and Geothermal Research, 198(3), 2010, 297-310.

[3]. A. Germa, Evolution volcano-tectonique de l'île de la Martinique (arc insulaire des Petites Antilles): nouvelles contraintes géochronologiques et géomorphologiques, Doctoral dissertation, Université Paris Sud-Paris XI, 2008.

[4]. P. Joseph, How Should the Forest Types of the Lesser Antilles be Described in the Intertropical Area, Earth Resources, 1(3), 2013, 78-102.

[5]. P. Joseph, The Influence of Vegetation on the Main Macro-Climatic Factors: the Example of the Lower Vegetal Floor of Martinique (Lesser Antilles), Open Jounal of Botany (OJB), 1(1), 2014), 5-18.

[6]. A.C. Moreira, and J.M.S. Martins, Influence of site factors on the impact of Phytophthora cinnamomi in cork oak stands in Portugal, Forest Pathology, 35(3), 2005, 145-162.

[7]. D. Alard, andI. Poudevigne, Factors controlling plant diversity in a rural landscape: a functional approach, Landscape and Urban Planning, 46(1), 1999, 29-39.

[8]. A. Coronato, C. Roig, L. Collado, andF. Roig, Geomorphologic emplacement and vegetation characteristics of Fuegian peatlands, southernmost Argentina, South America, Developments in Earth Surface Processes, 9, 2006, 111-128.

[9]. M. Rouissi, D. Boix, S.D. Muller, S. Gascón, A. Ruhí, J. Sala, andA. Daoud-Bouattour, Spatio-temporal variability of faunal and floral assemblages in Mediterranean temporary wetlands, Comptes rendus biologies,337(12), 2014, 695-708.

[10]. S.Z. Dobrowski, A climatic basis for microrefugia: the influence of terrain on climate. Global change biology, 17(2), 2011, 10221035 .

[11]. K.X., Whipple, E. Kirby, andS.H. Brocklehurst, Geomorphic limits to climate-induced increases in topographic relief, Nature, 401(6748), 1999, 39-43.

[12]. F.M. Salama, S.M. El Naggar, andK.A. Baayo, Vegetation structure and environmental gradients in the Sallum area, Egypt, Ecol Mediterr, 31(1), 2005, 15-32

[13]. P. Roche, T. Tatoni, andF. Médail, Relative importance of abiotic and land use factors in explaining variation in woody vegetation in a French rural landscape, Journal of Vegetation Science, 9(2), 1998 221-228.

[14]. E. Tabacchi, A.M. Planty-Tabacchi, and O. Décamps, Continuity and discontinuity of the riparian vegetation along a fluvial corridor, Landscape Ecology, 5(1), 1990, 9-20.

[15]. R.H. Whittaker, Gradient analysis of vegetation, Biological reviews,42(2), 1967, 207-264

[16]. C. Ezcurra, N. Baccalá, and P. Wardle, Floristic relationships among vegetation types of New Zealand and the Southern Andes: similarities and biogeographic implications, Annals of botany, 101(9), 2008, 1401-1412.

[17]. P. Joseph, The vegetation of the Lesser Antilles: floristic diversity and ecosystemic dynamics, International Journal of Environmental Studies, 69(5), 2012, 816-833.

[18]. E. Noumi, Floristic inventory of woody species in the Manengouba mountain forest, Cameroon, Journal of Biology and Life Science, 4(2), 2013, 282-309.

[19]. G. Imani, L. Zapfack, J. Kalume, B. Riera, L. Cirimwami, and F. Boyemba, Woody vegetation groups and diversity along the altitudinal gradient in mountain forest: case study of Kahuzi-Biega National Park and its surroundings, RD Congo, Journal of Biodiversity and Environmental Sciences, 8,2016 , 134-150.

[20]. D. Monticelli, Altitudinal distribution and diversity of the Mount Karthala bird community on Grand Comoro (Comoro Islands), Tropical Zoology, 25(3), 2012, 109-126.

[21]. P. Joseph, Dynamique, écophysiologie végétales en bioclimat sec à la Martinique (Antilles françaises), Doctorat nouveau régime, Université des Antilles et de la Guyane, Martinique,1997.

[22]. A. Germa, X. Quidelleur, S. Labanieh, C. Chauvel, andP. Lahitte, The volcanic evolution of Martinique Island: Insights from K-Ar dating into the Lesser Antilles arc migration since the Oligocene, Journal of Volcanology and Geothermal Research, 208(3), 2011, $122-135$

[23]. T.F. Rangel, J.A.F. Diniz- Filho, andL.M. Bini, SAM: a comprehensive application for spatial analysis in macroecology, Ecography, 33(1), 2010, 46-50.

[24]. C. F Dormann, J. M McPherson, M. B Araújo, R. Bivand, J. Bolliger, G. Carl, andI. Kühn, Methods to account for spatial autocorrelation in the analysis of species distributional data: a review, Ecography, 30(5), 2007, 609-628.

[25]. T.M. Blackburn, Method in macroecology, Basic and Applied Ecology, 5(5), 2004, 401-412.

[26]. A.K. Jain, M.N. Murty, andP.J. Flynn, Data clustering: a review, ACM computing surveys (CSUR), 31(3), 1999, $264-323$. 